\title{
Thioalkyl- and Sulfone-Substituted Poly(p-Phenylene Vinylene)s
}

\author{
Martina Rimmele, ${ }^{\dagger}$ Klaus Ableidinger, ${ }^{\dagger}$ Adam V. Marsh, ${ }^{\ddagger}$ Nathan J. Cheetham, ${ }^{\S}$ M. Josef \\ Taublaender, ${ }^{\prime \dagger}$ Alina Buchner, ${ }^{\dagger}$ Jonathan Prinz, ${ }^{\dagger}$ Johannes Fröhlich, ${ }^{\dagger}$ Miriam M. Unterlass, ${ }^{\| \dagger}$ \\ Martin Heeney, ${ }^{\ddagger}$ Florian Glöcklhofer ${ }^{\dagger, \ddagger} * *$ \\ ${ }^{\dagger}$ Institute of Applied Synthetic Chemistry, TU Wien, Getreidemarkt 9/163, 106o Vienna, Austria. \\ ${ }^{\ddagger}$ Department of Chemistry and Centre for Plastic Electronics, Imperial College London, London W12 oBZ, UK. \\ $\S$ Department of Physics and Centre for Plastic Electronics, Imperial College London, London SW7 2AZ, UK. \\ " Institute of Materials Chemistry, TU Wien, Getreidemarkt 9/165, 106o Vienna, Austria.
}

\begin{abstract}
Poly(p-phenylene vinylene)s (PPVs) have been studied for decades, but research on this interesting class of conjugated polymers is far from being completed. New applications like in bioimaging keep emerging and even simple structural variations are still waiting to be explored. Surprisingly, not even dithioalkyl-substituted PPVs (S-PPVs) have been reported in the peer-reviewed literature, although the corresponding dialkoxy-substituted PPVs (O-PPVs) like MEH-PPV or MDMO-PPV are most frequently used and although thioalkyl substituents can improve the material properties significantly. We herein report the development of a highly efficient, scalable two-step synthesis of Gilch monomers for S-PPVs starting from low-cost 1,4-diiodobenzene. A low-temperature polymerization protocol has been developed for these monomers, affording high-molecular weight S-PPVs in excellent yields. The thermal, electrochemical, and photophysical properties of S-PPVs are reported to highlight the potential of these polymers. Furthermore, treatment with dimethyldioxirane is demonstrated to result in rapid conversion into sulfone-substituted PPVs $\left(\mathrm{SO}_{2}-\mathrm{PPVs}\right)$, introducing a route to high-molecular weight $\mathrm{SO}_{2}$-PPVs with exceptional stability and solid-state photoluminescence quantum yields of up to 0.46.
\end{abstract}

\section{INTRODUCTION}

Poly(p-phenylene vinylene)s (PPVs) have shaped the field of organic electronics and had a strong impact on many other fields of research. Nevertheless, despite their status as the materials of choice for fundamental research on conjugated polymers,,$^{1-3}$ the synthetic chemistry of this interesting class of polymers is still "far from being mission accomplished" (as we highlight by this work). . Furthermore, exciting new applications like in bioimaging and drug delivery are emerging, making use of the excellent fluorescence properties, the low toxicity, and the biocompatibility of PPVs. ${ }^{3-5}$

For most applications of PPVs, substituents are attached to the conjugated polymer backbone. The substituents render the polymers soluble, but they are also useful to adjust the electronic, spectral, morphological, and self-assembly properties. ${ }^{1}$ Most frequently, alkoxy substituents are attached; dialkoxy-substituted PPVs (O-PPVs, Scheme 1 a) have become the best investigated substituted PPVs. However, remarkably, there is not a single report of their dithioalkyl-substituted analogs (S-PPVs, Scheme $1 \mathrm{~b}$ ) in the peer-reviewed literature. This is surprising as replacing alkoxy by thioalkyl substituents is known to be a small, but very effective structural variation. Most likely, this gap in PPV research is due to difficulties in the preparation of S-
PPVs, which prevented a proper investigation of these polymers.

Scheme 1. Polymer structures of (a) dialkoxy- (OPPVs) and (b) dithioalkyl-substituted PPVs (S-PPVs), examples with different alkyl groups $\left(R, R^{\prime}\right)$.
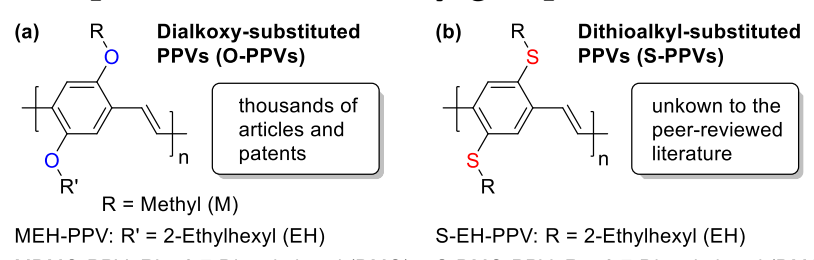

S-EH-PPV: R = 2-Ethylhexyl $(E H)$ MDMO-PPV: R' = 3,7-Dimethyloctyl (DMO) S-DMO-PPV: R = 3,7-Dimethyloctyl (DMO)

For other conjugated polymers, replacing alkoxy by thioalkyl substituents is well investigated. ${ }^{6}$ Intermolecular S...S interactions can facilitate the $\pi$-stacking of polymer chains and thereby improve the charge carrier mobilities. ${ }^{7,8}$ Furthermore, thioalkyl substituents show significantly weaker electron-donating properties than alkoxy substituents, which can be rationalized by the poorer overlap of their orbitals with the $\pi$-system of the conjugated polymer backbone, as a result of the larger size of the sulfur atom. ${ }^{9}$ To some extent, thioalkyl substituents can also accept $\pi$-electrons from the polymer backbone, primarily through a lowlying antibonding $\sigma$-orbital. ${ }^{10}$ The combined effects often result in lower highest occupied molecular orbital (HOMO) and lowest unoccupied molecular orbital 
(LUMO) energy levels. The lower energy levels can improve the stability of the polymers, facilitate electron injection from metal electrodes, result in more balanced transport of holes and electrons, and increase the open-circuit voltage when used in solar cells. ${ }^{6,11}$ However, these effects strongly depend on the particular polymer structure, as torsional twisting induced by the larger size of the sulfur atom can change the conformation of the polymer backbone and reduce the effective conjugation length, resulting in unexpectedly wide band gaps and blue-shifted absorption. ${ }^{12,13}$ Conformational changes can also outweigh the positive effects of intermolecular S...S interactions on the material properties. ${ }^{14}$ However, such negative conformational effects were not expected for S-PPVs (see Supporting Information (SI)), which prompted our immense interest in preparing these polymers.

Moreover, we expected S-PPVs to be useful precursors for the synthesis of high-quality sulfone-substituted PPVs ( $\mathrm{SO}_{2}$-PPVs, Scheme $2 \mathrm{a}$ ) by post-polymerization oxidation. $\mathrm{SO}_{2}$-PPV was previously prepared by Stille coupling and found to be a strong electron acceptor as well as an excellent light emitter, with a fluorescence quantum yield of 0.95 in solution. ${ }^{15}$ However, Stille coupling yielded rather low-molecular weight polymers and the ${ }^{1} \mathrm{H}$ NMR spectrum indicated a high number of structural defects. These are inherent issues of Stille polymerization that can be avoided by oxidation of S-PPVs prepared by other methods.

Generally, the material properties of PPVs can depend dramatically on the polymerization method; several polymerization methods are available beside Stille coupling. ${ }^{.}$Previous attempts to prepare S-PPVs by Gilch polymerization were reported in conference preprints..$^{16,17}$ It seems that the outlined preparation of the monomers was successful and that polymers were obtained, but experimental details on the monomer preparation were not provided and consistent information on the polymerization conditions as well as characterization results are missing. Nevertheless, we agree that Gilch polymerization is an excellent choice to prepare S-PPVs, as it should yield very high-molecular weight polymers and is the most convenient and versatile method for PPV preparation.

Rehahn et al. provided an excellent overview of the mechanistic knowledge and challenges of the Gilch polymerization. ${ }^{18}$ In the first step, substituted $\alpha, \alpha^{\prime}$-dihalogenated $\mathrm{p}$ xylenes are converted into $\alpha$-halogenated p-quinodimethanes by 1,6-elimination of hydrogen halide upon addition of a base. These p-quinodimethanes are the active monomers that afford a non-conjugated precursor polymer upon radical polymerization, which then undergoes another elimination to yield PPVs (Scheme 2 b). The polymerization is initiated by diradicals, usually formed by thermal dimerization of the active monomers. ${ }^{3}$

Besides advantages on a small scale, Gilch polymerization is also an economical method for the industrial scale preparation of O-PPVs. ${ }^{1}$ The industrial interest arises from the low price and the convenient accessibility of the starting materials and reagents, as well as from the simple preparation and purification of the polymers..$^{18}$ However, most of these advantages did not apply for the preparation of the S-PPVs. The monomer synthesis outlined in the preprints was carried out in as many as five steps starting from rather expensive diethyl 2,5-dihydroxyterephthalate and the polymerization caused severe issues ranging from very low yields to insolubility of the polymers and - most likely - a lack of reproducibility.

Scheme 2. (a) Polymer structure of sulfone-substituted PPV ( $\left.\mathrm{SO}_{2}-\mathrm{PPV}\right),(\mathrm{b})$ synthesis of PPV by Gilch polymerization on the example of O-PPV: 1,6-elimination of hydrogen halide (HX) and subsequent radical polymerization afford a precursor polymer, which forms PPV in a second elimination step.

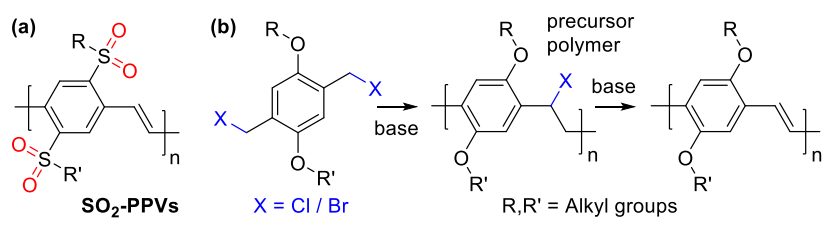

It was our aim to (i) develop a short and simple low-cost synthesis of the Gilch monomers for S-PPVs, (ii) find reliable polymerization conditions, (iii) investigate the postpolymerization oxidation of S-PPV to $\mathrm{SO}_{2}-\mathrm{PPV}$, and (iv) measure the thermal, electrochemical, and photophysical properties of the polymers.

\section{RESULTS AND DISCUSSION}

For designing a short and simple low-cost synthesis of the Gilch monomers for S-PPVs, we looked at the synthesis of the monomers for O-PPVs, which is done in two facile steps: (i) alkylation of 1,4-dihydroxybenzene or 1-hydroxy4-methoxybenzene, affording 1,4-di(alkoxy)benzenes, and (ii) subsequent chloro- or bromomethylation (see SI). Unfortunately, the corresponding alkylation of thiols is not a suitable reaction, as $1 \mathrm{~g}$ of the required thiols costs as much as $1 \mathrm{~kg}$ of the hydroxybenzenes. However, we achieved a convenient, high-yielding, low-cost preparation of different Gilch monomers for S-PPVs by a related approach (Scheme 3). The development of the reactions as well as the challenges faced are discussed in the following two subsections.

Scheme 3. Synthesis of Gilch monomers for S-PPVs in two/three steps starting from 1,4-diiodobenzene 1 .

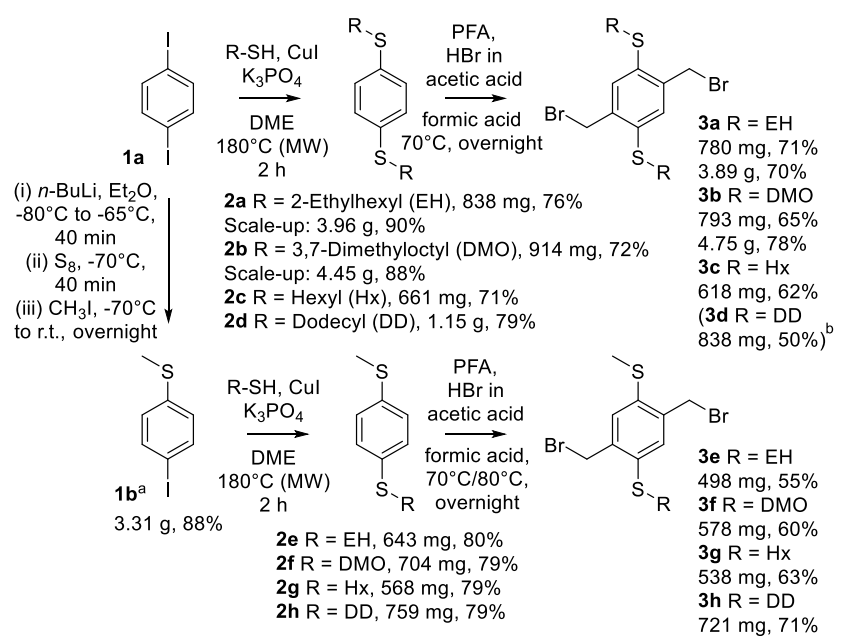


a used crude for further conversion, brequired alternative reaction conditions: paraformaldehyde (PFA), $\mathrm{HBr}$ in acetic acid, trifluoroacetic acid, trifluoroacetic anhydride, $80^{\circ} \mathrm{C}, 24 \mathrm{~h}$.

Synthesis of 1,4-di(thioalkyl)benzenes by microwaveassisted reactions. Instead of using thiols as starting materials, 1,4-di(thioalkyl)benzenes with two identical thioalkyl substituents (such as $2 \mathbf{2 a - d}$ ) can be prepared from 1,4dihalogenated benzenes by lithium-halogen exchange using $t$-butyllithium $(t$-BuLi) and subsequent addition of sulfur and alkyl iodide. ${ }^{19,20}$ Initially, we were following a similar approach by developing a method that allows for using alkyl bromides instead of alkyl iodides (see SI), as the bromides are available at much lower cost. However, the highly pyrophoric nature of $t$-BuLi is an undesirable risk, particularly on a larger scale. As a safer alternative, coupling of 1,4-diiodobenzene 1a with 2-ethylhexylthiol has been described to yield di(thioalkyl)benzene 2 a. $^{15}$ However, when following this approach, we found the work-up of this reaction to be tedious, due to the large amounts of DMF and CuI present (except for the synthesis of compound $\mathbf{2 d}$, which precipitated from the reaction medium and was simply filtered off (see SI)). As an additional disadvantage, the ligand used for this reaction, neocuproine, is far from being a low-cost reagent.

Fortunately, Anilkumar et al. recently reported a protocol for the coupling of aryl iodides with alkylthiols using 1,2-dimethoxyethane (DME) as a more convenient solvent, less $\mathrm{CuI}$ as catalyst, and low-cost 1,4-diazabicyclo[2.2.2] octane (DABCO) as ligand. ${ }^{21}$ We adapted this protocol for the twofold reaction of 1,4-diiodobenzene 1a, but the reaction took several days to be complete. Hence, we decided to develop a related microwave-assisted reaction protocol at higher temperatures (Table 1, entries 1-5). The initially used base, $\mathrm{K}_{2} \mathrm{CO}_{3}$, had to be replaced by $\mathrm{K}_{3} \mathrm{PO}_{4}$ to avoid pressure increase in the sealed vial as a result of $\mathrm{CO}_{2}$ formation. Interestingly, using this base, we did not observe any difference in conversion when leaving out the ligand $\mathrm{DABCO}$ (neither at $180^{\circ} \mathrm{C}$ in the microwave reactor nor at $120^{\circ} \mathrm{C}$ under conventional heating).

The final, optimized protocol allowed for a rapid synthesis of compounds 2a-d (Scheme 3) in two hours reaction time and good yields of $70-80 \%$ after purification by flash chromatography (Table 1 , entries 5-6). For a moderate scale-up of the synthesis of $\mathbf{2} \mathbf{a}$ and $\mathbf{2} \mathbf{b}$, four consecutive microwave reactions were carried out and combined for work-up (Table 1 , entries $7-8$ ), which resulted in even higher yields of about $90 \%$. Considering the high purity of the crude products, we assume that purification by methods other than flash chromatography (e.g. distillation) is feasible for large batches.

Table 1. Development of a CuI-catalyzed microwaveassisted reaction for the conversion of aryl iodides ra and 1 b into 1,4-di(thioalkyl)benzenes 2a-h (scale: 3.o mmol). Final reactions highlighted in grey. Scale-up carried out by four consecutive reactions and combined work-up (entries 9-10).

\begin{tabular}{|c|c|c|c|c|c|c|}
\hline & Target & Base & Ligand & $\begin{array}{c}\text { Temp. } \\
{\left[{ }^{\circ} \mathbf{C}\right]}\end{array}$ & $\begin{array}{c}\text { Timea } \\
{[\mathbf{m i n}]}\end{array}$ & $\begin{array}{c}\text { Yield } \\
{[\%]}\end{array}$ \\
\hline $\mathbf{1}$ & $\mathbf{2 d}$ & $\mathrm{K}_{2} \mathrm{CO}_{3}$ & $\mathrm{DABCO}$ & 160 & 10 & $\mathrm{n} / \mathrm{a}^{\mathrm{b}}$ \\
\hline $\mathbf{2}$ & $\mathbf{2 d}$ & $\mathrm{K}_{3} \mathrm{PO}_{4}$ & $\mathrm{DABCO}$ & 180 & 120 & 79 \\
\hline 3 & $\mathbf{2 d}$ & $\mathrm{K}_{3} \mathrm{PO}_{4}$ & $\mathrm{DABCO}$ & 180 & 60 & $\mathrm{n} / \mathrm{a}^{\mathrm{c}}$ \\
\hline 4 & $\mathbf{2 d}$ & $\mathrm{K}_{3} \mathrm{PO}_{4}$ & $\mathrm{DABCO}$ & 200 & 120 & 75 \\
\hline 5 & $\mathbf{2 d}$ & $\mathrm{K}_{3} \mathrm{PO}_{4}$ & - & 180 & 120 & 79 \\
\hline 6 & $\mathbf{2 a - c}$ & $\mathrm{K}_{3} \mathrm{PO}_{4}$ & - & 180 & 120 & 71 to \\
\hline 7 & $\mathbf{2 a}$ & $\mathrm{K}_{3} \mathrm{PO}_{4}$ & - & 180 & 120 & 90 \\
\hline 8 & $\mathbf{2 b}$ & $\mathrm{K}_{3} \mathrm{PO}_{4}$ & - & 180 & 120 & 88 \\
\hline 9 & $\mathbf{2 e - h}$ & $\mathrm{K}_{3} \mathrm{PO}_{4}$ & - & 180 & 120 & 79 to \\
& & & & & & $80^{\mathrm{d}}$ \\
\hline
\end{tabular}

a Reaction time after reaching $180^{\circ} \mathrm{C}$. ${ }^{\mathrm{b}}$ Reaction aborted after 10 min (maximum pressure of 22 bar exceeded). ${ }^{\text {c Reaction }}$ incomplete ( $25 \%$ single reacted intermediate and $75 \%$ product, according to ${ }^{1} \mathrm{H}$ NMR of crude product), not purified by flash chromatography. ${ }^{\mathrm{d}}$ See Scheme 3.

For the synthesis of 1,4-di(thioalkyl)benzenes with two different thioalkyl substituents (2e-h), we first tested if 1bromo-4-(thiomethyl)benzene could be used as starting material, as this compound is available at a reasonable price. However, conversion of this brominated starting material was limited to about $\mathbf{2 0} \%$, except for a slight increase to about 30\% when adding stoichiometric amounts of catalyst. Hence, we used 1-iodo-4-(thiomethyl)benzene $\mathbf{1 b}$ instead (Scheme 3), which was obtained from 1a in excellent yields following a published protocol using $n$ buthyllithium ( $n$-BuLi). ${ }^{22} \mathbf{1 b}$ was used for the microwave reactions without further purification after solvent extraction. Yields of about $80 \%$ were achieved for compounds $2 \mathbf{e}-$ h (Table 1, entry 9). Reaction times below two hours resulted in incomplete conversion.

Synthesis of Gilch monomers by bromomethylation of 1,4-di(thioalkyl)benzenes. For the final step of the monomer synthesis, we opted for bromomethylation instead of chloromethylation, as higher reactivity in Gilch polymerizations was reported when bromides are the leaving groups. ${ }^{23}$ The higher reactivity facilitates the monomer activation by 1,6-elimination, but should also result in more effective conversion of the precursor polymers into PPVs. (Indeed, we later observed formation of a red solution even when polymerizing at temperatures as low as $-60^{\circ} \mathrm{C}$, indicating that the precursor polymers are converted into S-PPVs.)

We previously developed a convenient protocol for the bromomethylation of 1,4-di(alkoxy)benzenes, which affords Gilch monomers for O-PPVs in quantitative yields (see SI). However, when subjecting 1,4-di(thioalkyl)benzene $\mathbf{2 e}$ to the same procedure, no product was obtained. Thin-layer chromatography (TLC) indicated unreacted starting material even after stirring for one week. Apparently, the weaker electron-donating properties of thioalkyl substituents impede electrophilic substitution. Another protocol, which was successful for the bromomethylation 
of 1-alkoxy-4-thioalkylbenzene employing acetic acid as the solvent, ${ }^{24}$ also failed.

Fortunately, when replacing acetic by formic acid as in a procedure reported by Sun et al., ${ }^{25}$ Gilch monomer 3 e could be obtained. Some optimization of the reaction resulted in $63 \%$ crude yield in an overnight reaction (see SI). Work-up was simply performed by precipitation into water followed by filtration and washing with methanol. However, the synthesis of ze required sealed reaction vials in this protocol to avoid a loss of formaldehyde and $\mathrm{HBr}$ at elevated temperatures. Such conditions constitute a safety issue, as decomposition of formic acid results in a significant pressure rise during the reaction.

For the final procedure, all these issues were solved. The bromomethylation was carried out in a three-necked flask equipped with a condenser and a $\mathrm{CaCl}_{2}$-filled drying tube. Repeated addition of paraformaldehyde (PFA) and $\mathrm{HBr}$ in acetic acid enabled high yields of about 60 to $80 \%$ for monomers $\mathbf{3 a - c}$ and 55 to $70 \%$ for monomers $\mathbf{3 e - h}$ (Scheme 3). Precipitation of the monomers was observed for all reactions. If this precipitation started too early, the reactions remained incomplete and had to be carried out at elevated temperatures of $80^{\circ} \mathrm{C}$ (instead of $70^{\circ} \mathrm{C}$ ). This ensured full conversion for the synthesis of all monomers, except for 3d. For work-up, the off-white precipitates were filtered, washed with methanol, and recrystallized from acetonitrile for high purity.

The necessity of using formic acid as the solvent was again confirmed for these final conditions. When using acetic acid for the synthesis of monomer za, but keeping all other parameters constant, no precipitation was observed. ${ }^{1} \mathrm{H}$ NMR spectroscopy (after work-up by solvent extraction) revealed that some product was formed, but several other signals were present. Most of these signals can be assigned to the single bromomethylated intermediate (see SI); the estimated product to intermediate ratio was 1:2.3.

Regarding the incomplete conversion of di(thioalkyl)benzene $\mathbf{2 d}$ into monomer $\mathbf{3} \mathbf{d}$ mentioned above, which is a result of the large alkyl groups and the poor miscibility with the reaction medium, we tested the addition of various tetraalkylammonium bromides as phase-transfer catalysts. Although this was reported to improve bromomethylations before, ${ }^{26}$ we did not observe any considerable effect. However, full conversion and yields of 50\% were achieved using trifluoroacetic acid and some trifluoroacetic anhydride as the reaction medium (Scheme 3) by adapting a procedure successful for similar compounds with large alkyl groups. ${ }^{27}$ The reactions in trifluoroacetic acid afforded a dark byproduct, which we found difficult to separate when testing the synthesis of other monomers than $3 \mathbf{d}$ (3a and $\mathbf{3} \mathbf{b}$ ), resulting in low yields and impure products.

Although we prepared monomers $3 \mathbf{a}-\mathbf{h}$ for Gilch polymerization, they are also useful for other reactions, such as the synthesis of dialdehydes or diphosphonates for HornerEmmons (poly)condensations, ${ }^{25}$ opening up additional routes to conjugated polymers with dithioalkyl-substituted phenylene units.
Preparation of S-PPVs by Gilch polymerization. Initial polymerization experiments were carried out at room temperature (r.t.), using monomers $3 \mathbf{a}$ and $\mathbf{3} \mathbf{b}$, dry tetrahydrofuran (THF) as the solvent, and $\mathrm{KOtBu}$ as the base (Scheme 4). During these initial experiments, we observed that reproducibility was a challenge. The polymerization yields (determined by precipitation into methanol, filtration and drying) fluctuated strongly and were usually low. We decided to address this issue by reversing the order of addition of monomer and base as well as by changing the suppliers of $\mathrm{KOtBu}$ (1.o M in THF) and THF. However, no improvement was observed until we discovered that precipitation of the $\mathrm{KO} t \mathrm{Bu}$ solution (when purging with argon prior to addition to the monomer solution) caused the issues. To avoid precipitation, we diluted the commercial 1.0 $\mathrm{M}$ solution with THF and purged with argon for only 2 min (4 min for larger scale polymerizations). This improved the reproducibility, but the polymerization yields remained moderate (Table 2, entries 1 and 4 ).

However, when adding the base at a low temperature of $-60^{\circ} \mathrm{C}$, keeping this temperature for $3 \mathrm{~h}$, warming to r.t. within $1 \mathrm{~h}$, and stirring at r.t. for another hour, higher yields were obtained (Table 2, entries 2 and 5). In addition to improved yields, low polymerization temperatures also result in fewer structural defects, which improves the polymer performance and the durability in devices. ${ }^{18,28}$ Nevertheless, temperatures below $-60^{\circ} \mathrm{C}$ must be avoided at any time of the polymerization, as we found this to significantly decrease the polymerization yields.

The preparation of the other S-PPVs $\mathbf{4} \mathbf{c}-\mathbf{h}$ was also carried out under the described low-temperature conditions. However, the weaker solubilizing effect of the alkyl groups of these polymers resulted in lower yields and considerably smaller soluble fractions, in particular for polymers $\mathbf{4} \mathbf{e}-\mathbf{h}$ (Table 2, entries 7-12). Hence, we focused on polymers 4a and $\mathbf{4} \mathbf{b}$ for further investigation and characterization. Interestingly, we could further improve the yields for these polymers by scaling-up the polymerization (Table 2 , entries 3 and 6); we observed this effect repeatedly for both polymers. Precipitation of the purified polymer solution obtained from Soxhlet extraction (instead of evaporation of the solvent) reduced the yield, but this facilitated redissolution of the polymers for characterization and modification, presumably for morphological reasons. Hence, we used the precipitated polymers (prepared on a larger scale) for further investigations.

Gel permeation chromatography (GPC) confirmed the expected high molecular weights. For polymer 4a, a mass average molecular weight $\left(\mathrm{M}_{\mathrm{w}}\right)$ of $431 \mathrm{kDa}$ and a number average molecular weight $\left(\mathrm{M}_{\mathrm{n}}\right)$ of $100 \mathrm{kDa}$ were measured ( $\mathrm{D}$ $=4.3)$, for polymer $4 \mathbf{b}, 87 \mathrm{kDa}\left(\mathrm{M}_{\mathrm{w}}\right)$ and $31 \mathrm{kDa}\left(\mathrm{M}_{\mathrm{n}}\right)(\bigoplus=$ 2.8). The lower values for polymer $\mathbf{4} \mathbf{b}$ are attributed to earlier precipitation during polymerization.

${ }^{1} \mathrm{H}$ NMR measurements of $\mathbf{4} \mathbf{a}$ and $\mathbf{4} \mathbf{b}$ confirmed that there were no considerable structural defects (see SI). Infrared (IR) spectra showed the characteristic aliphatic $\mathrm{C}-\mathrm{H}$ stretching modes around $2900 \mathrm{~cm}^{-1}$ (resulting from the side chains) as well as the aromatic and vinylic $\mathrm{C}-\mathrm{H}$ stretching 
modes slightly above $3000 \mathrm{~cm}^{-1}$ (originating from the polymer backbone) (see SI). Both polymers exhibit an intense mode close to $970 \mathrm{~cm}^{-1}$, which confirms the formation of $\mathrm{HC}=\mathrm{CH}$ trans-double bonds; the characteristic $\mathrm{HC}=\mathrm{CH}$ mode for cis-double bonds in the expected region of 890 to $900 \mathrm{~cm}^{-1}$ is very weak, indicating a high cis-trans selectivity of the polymerization. ${ }^{29}$

Scheme 4. Preparation of S-PPVs $4^{a-h}$ by Gilch polymerization at r.t. or $-60^{\circ} \mathrm{C}$.
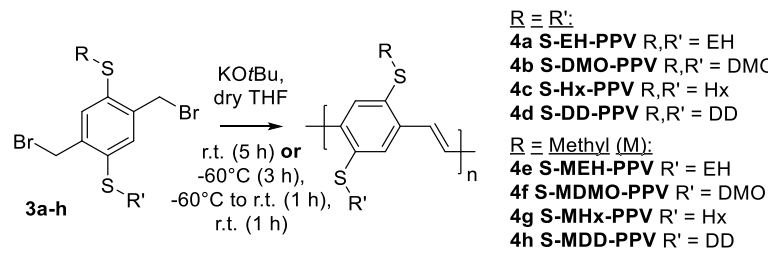

Table 2. Gilch polymerization reactions at different conditions. Crude yield determined by precipitation into methanol, followed by filtration and drying. $\mathrm{Pu}$ rified yield after removing impurities with methanol and $n$-hexane in a Soxhlet extractor, extracting the polymer with $\mathrm{CHCl}_{3}$, and evaporating the solvent.

\begin{tabular}{|c|c|c|c|c|c|}
\hline polymer & $\begin{array}{c}\text { Target } \\
\text { Temp. }\end{array}$ & $\begin{array}{c}\text { Scale } \\
{[\mathbf{m m o l}]}\end{array}$ & $\begin{array}{c}\text { Crude } \\
\text { yield } \\
{[\%]}\end{array}$ & $\begin{array}{c}\text { Purified } \\
\text { yield [\%] }\end{array}$ \\
\hline $\mathbf{1}$ & $\mathbf{4 a}$ & r.t. & 0.30 & 61 & 55 \\
\hline $\mathbf{2}$ & $\mathbf{4 a}$ & $-60^{\circ} \mathrm{C}$ & 0.30 & 73 & 68 \\
\hline 3 & $\mathbf{4 a}$ & $-60^{\circ} \mathrm{C}$ & 1.0 & 90 & $88 / 82^{\mathrm{a}}$ \\
\hline 4 & $\mathbf{4 b}$ & r.t. & 0.30 & 52 & 47 \\
\hline 5 & $\mathbf{4 b}$ & $-60^{\circ} \mathrm{C}$ & 0.30 & 64 & 56 \\
\hline 6 & $\mathbf{4 b}$ & $-60^{\circ} \mathrm{C}$ & 1.0 & 77 & $67 / 29^{\mathrm{a}}$ \\
\hline 7 & $\mathbf{4} \mathbf{c}$ & $-60^{\circ} \mathrm{C}$ & 0.30 & 62 & 19 \\
\hline 8 & $\mathbf{4 d}$ & $-60^{\circ} \mathrm{C}$ & 0.30 & 60 & 17 \\
\hline 9 & $\mathbf{4 e}$ & $-60^{\circ} \mathrm{C}$ & 0.30 & 67 & 4 \\
\hline 10 & $\mathbf{4 f}$ & $-60^{\circ} \mathrm{C}$ & 0.30 & 49 & 6 \\
\hline 11 & $\mathbf{4 g}$ & $-60^{\circ} \mathrm{C}$ & 0.30 & 41 & 8 \\
\hline 12 & $\mathbf{4 h}$ & $-60^{\circ} \mathrm{C}$ & 0.30 & 37 & 5 \\
\hline
\end{tabular}

a Yield obtained by pouring the $\mathrm{CHCl}_{3}$ solution from Soxhlet extraction into methanol for precipitation and filtering off and drying the polymer (instead of evaporating the solvent).

Preparation of $\mathrm{SO}_{2}-\mathrm{PPVs}$ by post-polymerization oxidation of S-PPVs. Dimethyldioxirane (DMDO) can be used for selective post-polymerization oxidation of thioalkyl-substituted conjugated polymers to sulfone-substituted polymers. ${ }^{20,30}$ Treating S-PPVs $4 \mathbf{a}$ and $\mathbf{4} \mathbf{b}$ with DMDO yielded $\mathrm{SO}_{2}$-PPVs $5 \mathbf{a}$ and $\mathbf{5} \mathbf{b}$ (Scheme 5 ) within seconds; a drastic change of the fluorescence properties was observed (see videos in SI). Conveniently, oxidation with DMDO yields acetone as the only side product, which can be easily removed by evaporation together with the solvent and excessive reagent. Doing so, the oxidized polymers were obtained in yields of exactly $100 \%$.
Scheme 5. Post-polymerization oxidation of S-PPVs 4 a and $4 \mathrm{~b}$ to $\mathrm{SO}_{2}$-PPVs $5 \mathrm{a}$ and $5 \mathrm{~b}$ using dimethyldioxirane (DMDO). Synthesis of oxidized Gilch monomer $3 \mathrm{a}^{-\mathrm{SO}_{2}}$ and attempted polymerization.

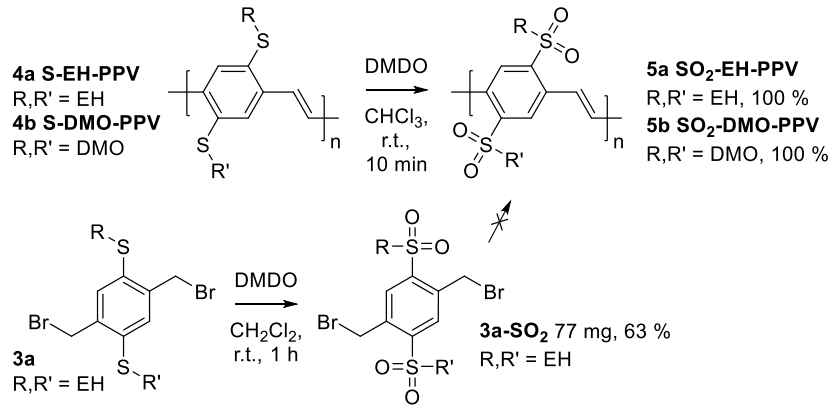

GPC and ${ }^{1} \mathrm{H}$ NMR measurements could not be carried out for the oxidized polymers, as the solubility was found to be very low. In contrast, $\mathrm{SO}_{2}$-EH-PPV prepared by Stille coupling was reported to be readily soluble in common organic solvents. ${ }^{15}$ We attribute the differences in solubility to the significantly higher molecular weight of our polymers (the chain length is expected to be unaffected by the oxidation) and to higher cis-trans selectivity of the polymerization. For applications, processing the polymers before oxidation followed by post-processing oxidation is potentially a feasible approach to circumvent solubility issues.

As expected, the oxidation gives rise to significant changes in the IR spectra. Most notably, it results in the appearance of very indicative $\mathrm{SO}_{2}$ modes at $1145 \mathrm{~cm}^{-1}$ (symmetric stretching) and $1310 \mathrm{~cm}^{-1}$ (asymmetric stretching) (see $\mathrm{SI}$ ). The spectra again show the characteristic aliphatic $\mathrm{C}-\mathrm{H}$ stretching modes around $2900 \mathrm{~cm}^{-1}$ and above $3000 \mathrm{~cm}^{-1}$. The configuration of the double bonds appears to be unaffected.

For comparison, we also wanted to prepare $\mathrm{SO}_{2}-\mathrm{PPVs}$ by Gilch polymerization of oxidized monomers such as $3 \mathbf{a}-$ $\mathrm{SO}_{2}$ (Scheme 5). However, the reaction rapidly turned dark when adding $\mathrm{KO} t \mathrm{Bu}$ at $-60^{\circ} \mathrm{C}$; no polymer was obtained upon precipitation into methanol. Presumably, the electron-withdrawing properties of the sulfone groups prevent the formation of halogenated p-quinodimethanes that are required as the active monomers. Nevertheless, $\mathbf{3 a}^{\mathbf{a}-\mathbf{S O}_{2}}$ may be a useful precursor for the synthesis of monomers for other polymerization methods.

Thermal properties of the S-PPVs and $\mathrm{SO}_{2}$-PPVs. The thermal stability of $\mathbf{4 a}, \mathbf{4} \mathbf{b}, \mathbf{5} \mathbf{a}$, and $\mathbf{5} \mathbf{b}$ was investigated by thermogravimetric analysis (TGA) (see SI). The decomposition temperatures of the S-PPVs were as high as $367^{\circ} \mathrm{C}$ (4a) and $378^{\circ} \mathrm{C}(\mathbf{4} \mathbf{b})$. Both polymers show literally no mass loss below $300^{\circ} \mathrm{C}$ and the mass loss at $350^{\circ} \mathrm{C}$ is still below $4 \%$. In contrast, the $\mathrm{SO}_{2}-\mathrm{PPVs}$ exhibited a continuous mass loss to approximately $8 \%$ at $300^{\circ} \mathrm{C}$, which starts around $100^{\circ} \mathrm{C}$. We attribute this mass loss to adsorbed water, as $\mathrm{SO}_{2}$ containing polymers can strongly adsorb water by hydrogen bonds. ${ }^{31}$ The decomposition temperatures of the $\mathrm{SO}_{2}$-PPVs were marginally lower than of the S-PPVs, $364^{\circ} \mathrm{C}$ (5a) and $372^{\circ} \mathrm{C}(\mathbf{5 b})$.

Electrochemical properties of S-PPVs and $\mathrm{SO}_{2}$-PPVs. Cyclic voltammetry $(\mathrm{CV})$ measurements were carried out 
to estimate the HOMO and LUMO energy levels of the polymers from the oxidation and reduction onsets (Figure 1, Table 3). The energy levels of S-PPVs $\mathbf{4 a}$ and $\mathbf{4} \mathbf{b}$ are $0.5-0.6$ $\mathrm{eV}$ lower than reported for MEH-PPV (Scheme 1) prepared by Gilch polymerization (LUMO: $-2.7 \mathrm{eV}$, HOMO: -5.02 $\mathrm{eV})^{32}$ and about $0.3 \mathrm{eV}$ lower than given for commercially available MEH-PPV, which aligns well with the expected effects of replacing alkoxy by thioalkyl groups. The oxidation to sulfones results in even lower HOMO and LUMO energy levels, as determined for $\mathrm{SO}_{2}-\mathrm{EH}-\mathrm{PPV} 5 \mathbf{a}$. The HOMO energy level of this polymer was estimated by subtracting the optical bandgap energy from the LUMO energy level, as the oxidation onset could not be measured reliably with our set-up. The results are in good agreement with $\mathrm{SO}_{2}$-EH-PPV prepared by Stille coupling. ${ }^{15}$ Interestingly, considering the LUMO-LUMO offset of $0.39 \mathrm{eV}$, allpolymer solar cells of $4 \mathbf{a}$ (as donor) and $5 \mathbf{a}$ (as acceptor) may be feasible, which may be an exciting future application of the demonstrated post-polymerization oxidation. Polymer $\mathbf{5 b}$ could not be processed into thin-films due to insolubility and hence has not been measured.

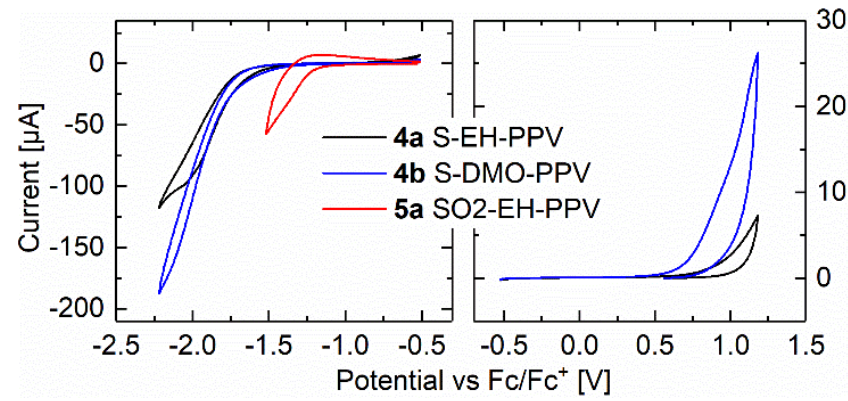

Figure 1. Cyclic voltammograms of drop cast thin-films of polymers $\mathbf{4 a}, \mathbf{4} \mathbf{b}$, and $\mathbf{5} \mathbf{a}$ on indium tin oxide (ITO) electrodes, reduction (left) and oxidation (right).

Table 3. Reduction and oxidation onset potentials ( $E_{\text {red }}$ and $\left.E_{o x}\right)$, bandgap energy $\left(E_{g}\right)$, and estimated HOMO and LUMO energy levels of drop cast thinfilms of polymers $4 a, 4 b$, and $5 a$.

\begin{tabular}{|c|c|c|c|c|}
\hline & $\begin{array}{l}\mathbf{E}_{\mathrm{red}} / \mathbf{E}_{\mathbf{o x}} \mathbf{V s} \\
\mathbf{F c} / \mathbf{F C}^{+}[\mathrm{V}]^{\mathrm{a}}\end{array}$ & $\begin{array}{c}\mathrm{E}_{\mathrm{g}}[\mathrm{eV}] \\
\left(\mathrm{CV} / \mathrm{opt}^{b}\right)\end{array}$ & $\begin{array}{c}\text { LUMO } \\
{[\mathrm{eV}]\left(\mathrm{CV}^{\mathrm{c}}\right)}\end{array}$ & $\begin{array}{c}\text { HOMO [eV] } \\
\left(\mathrm{CV}^{\mathrm{c}} / \mathrm{opt}^{d}\right)\end{array}$ \\
\hline $4 a$ & $-1.53 / 0.74$ & $2.27 / 2.24$ & -3.27 & $-5 \cdot 54 /-5 \cdot 51$ \\
\hline $4 b$ & $-1.53 / 0.66$ & $2.19 / 2.16$ & -3.27 & $-5 \cdot 46 /-5.43$ \\
\hline $5 a$ & -1.14/n.a. & n.a./2.47 & -3.66 & n.a./-6.13 \\
\hline
\end{tabular}

a See SI for determination. ${ }^{b}$ Determined from the absorption onset (see Table 3). ${ }^{\mathrm{c}}$ Calculated from the reduction and oxidation onsets on the premise that the $\mathrm{Fc} / \mathrm{Fc}^{+}$energy level is $-4.80 \mathrm{eV}$. ${ }^{\mathrm{d}}$ Determined by subtracting the optical bandgap energy from the LUMO level.

Photophysical properties of S-PPVs and $\mathrm{SO}_{2}$-PPVs. Polymers 4a, $\mathbf{4} \mathbf{b}$, and $\mathbf{5}$ a show very similar absorption spectra in solution (Figure 2, left) with a maximum at about 450 $\mathrm{nm}$ for all three polymers (Table 4). Remeasuring the solutions after storing in a flask under air and ambient light for 5 days (Figure 2, dashed lines) indicates that even dissolved in $\mathrm{CHCl}_{3}$ photobleaching is weak for polymers $4 \mathbf{a}$ and $\mathbf{4} \mathbf{b}$ (approx. 10\% lower absorption at the maximum) and almost non-existent for polymer $\mathbf{5 a}$ ( $2 \%$ lower absorption at the maximum).

The photoluminescence (PL) spectra of $\mathbf{4} \mathbf{a}$ and $\mathbf{4} \mathbf{b}$ in solution are identical (Figure 2, right). In contrast, the PL maximum of polymer $5 \mathbf{a}$ is blue-shifted by $27 \mathrm{~nm}$, but the spectrum features an additional shoulder close to the PL maximum wavelength of $\mathbf{4} \mathbf{a}$ and $\mathbf{4} \mathbf{b}$. The smaller Stokes shift of $5 \mathbf{a}$ is considered to be a result of higher rigidity of the polymer backbone induced by the sterically demanding sulfone groups.

In thin-films, both the absorption and the PL of S-DMOPPV $\mathbf{4} \mathbf{b}$ are red-shifted compared to S-EH-PPV $4 \mathbf{a}$ (Figure 3, Table 4), which indicates stronger interactions of the polymer backbones enabled by the less bulky DMO side chains. Nevertheless, the large Stokes shifts (4a: $137 \mathrm{~nm}$, 4b: $160 \mathrm{~nm}$, cp. MEH-PPV: $66 \mathrm{~nm}^{32}$ ) indicate strong intermolecular interactions for both polymers, as expected as a result of S...S interactions. As in solution, the PL of $\mathrm{SO}_{2}-$ EH-PPV 5a is blue-shifted compared to its non-oxidized counterpart; however, in thin films, the absorption is blueshifted too, indicating weaker interactions of the polymer backbones due to the bulkiness of the sulfone groups and the absence of S...S interactions. The Stokes shift of 5a (101 $\mathrm{nm}$ ) is significantly smaller than for the non-oxidized polymers. Polymer $\mathbf{5} \mathbf{b}$ could not be measured in solution or processed into thin-films due to insolubility.

The solid-state photoluminescence quantum efficiencies (PLQEs, Table 4) were estimated measuring the polymers as obtained after work-up (no processing into thin-films). Polymer $\mathbf{4} \mathbf{a}$ is strongly fluorescent directly after precipitation and filtration (see SI for pictures), but the PLQE of both, $4 \mathbf{a}$ and $\mathbf{4} \mathbf{b}$, was found to be below 0.10 after drying (cf. MEH-PPV: 0.10-0.1533). We assume that strong intermolecular interactions deteriorate the PL properties, but render these polymers interesting for applications other than light emission. In contrast, very high solid-state PLQEs of 0.36 and 0.46 were measured for the oxidized polymers $5 \mathbf{a}$ and $\mathbf{5} \mathbf{b}$. Notably, the PLQEs were lower, if 4.50 equiv DMDO (instead of 4.05 equiv) were used for the post-polymerization oxidation (see SI), but the thin-film PL spectra were identical for both batches of $\mathrm{SO}_{2}-\mathrm{EH}-\mathrm{PPV}$ 5a. PLQEs in solution have not been measured, but were as high as 0.95 for $\mathrm{SO}_{2}$-EH-PPV prepared by Stille coupling. ${ }^{15}$

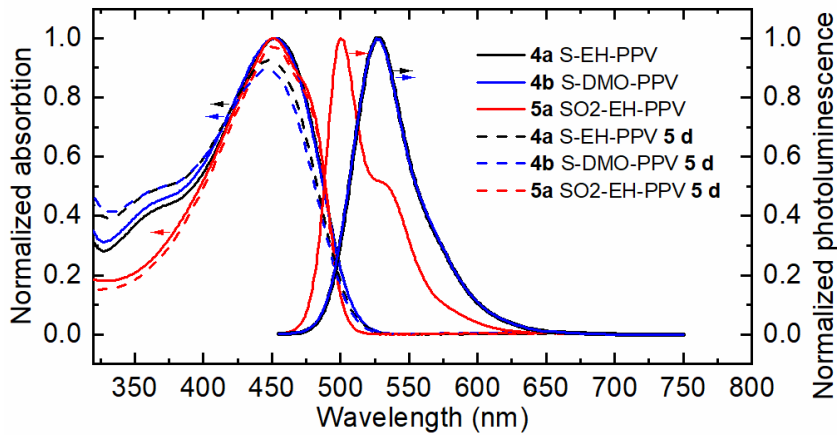

Figure 2. Solid lines: Normalized absorption and photoluminescence (PL) of polymers $\mathbf{4 a}, \mathbf{4} \mathbf{b}$, and $\mathbf{5} \mathbf{a}$ in solution $\left(\mathrm{CHCl}_{3}\right)$. PL excitation wavelength: $450 \mathrm{~nm}$. Dashed lines: 
Absorption spectra after storing the solutions under air and ambient light for 5 days to assess the photobleaching, normalized to the initial measurement.

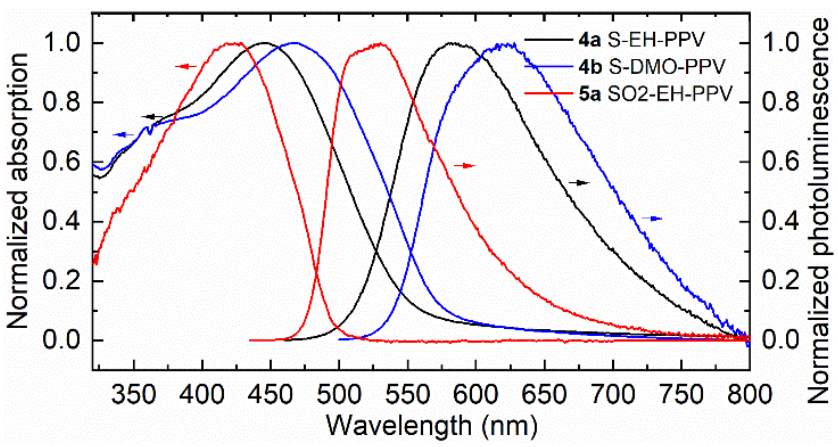

Figure 3. Normalized thin-film absorption and photoluminescence (PL) of polymers $\mathbf{4 a}, \mathbf{4} \mathbf{b}$, and $\mathbf{5} \mathbf{a}$. PL excitation wavelengths: $440 \mathrm{~nm}$ (4a), $480 \mathrm{~nm}(\mathbf{4} \mathbf{b}), 425 \mathrm{~nm}(\mathbf{5 a})$.

Table 4. Overview of photophysical properties in solution and solid state (thin-films and as obtained after work-up).

\begin{tabular}{|c|c|c|c|c|c|c|}
\hline & \multicolumn{2}{|c|}{ Solution } & \multicolumn{3}{c|}{ Solid (thin-film) } & Solid \\
\hline & $\begin{array}{c}\lambda_{\text {abs,max }} \\
{[\mathrm{nm}]}\end{array}$ & $\begin{array}{c}\lambda_{\text {PL,max }} \\
{[\mathrm{nm}]}\end{array}$ & $\begin{array}{c}\lambda_{\text {abs,max }} \\
{[\mathrm{nm}]}\end{array}$ & $\begin{array}{c}\lambda_{\text {PL,max }} \\
{[\mathrm{nm}]}\end{array}$ & $\begin{array}{c}\lambda_{\text {abs,onset }} \\
{[\mathrm{nm}]}\end{array}$ & PLQE $^{\text {a }}$ \\
\hline $\mathbf{4 a}$ & 453 & 527 & 445 & 582 & 554 & 0.08 \\
\hline 4b $^{\mathbf{b}}$ & 453 & 526 & 468 & 628 & 573 & 0.05 \\
\hline 5a & 451 & 500 & 429 & 530 & 502 & 0.36 \\
\hline 5b & n.a. $^{\text {b }}$ & n.a. $^{\text {b }}$ & n.a. $^{\text {b }}$ & n.a. $^{\text {b }}$ & n.a. $^{\text {b }}$ & 0.46 \\
\hline
\end{tabular}

a Estimated error: \pm 0.05 , excitation wavelength: $415 \mathrm{~nm}(4 \mathrm{a}$,

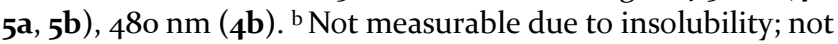
processable into thin-films.

\section{EXPERIMENTAL SECTION}

Reagents and solvents were purchased from commercial suppliers and used without further purification. Anhydrous THF was prepared by filtration through drying columns. 3,7-Dimethyl-1-octanethiol used in the synthesis of compound $\mathbf{2 b}$ was prepared via the respective bromide following published protocols starting from 3,7-dimethyl-1octanol (see SI).34,35 All reactions temperatures were monitored internally using a thermometer.

Synthesis of 1-iodo-4-(thiomethyl)benzene 1 b. A solution of 1,4-diiodobenzene ( $4.95 \mathrm{~g}, 15.0 \mathrm{mmol}, 1.0$ equiv) in dry $\mathrm{Et}_{2} \mathrm{O}(150 \mathrm{~mL})$ was cooled to $-80^{\circ} \mathrm{C}$ under argon. $n$-BuLi (2.5 $\mathrm{M}$ in hexanes, $6.6 \mathrm{~mL}, 16.5 \mathrm{mmol}$, 1.1 equiv) was added slowly and the reaction stirred for 40 min while slowly warming to $-65^{\circ} \mathrm{C}$. Subsequently, the reaction was cooled to $-70^{\circ} \mathrm{C}$ and sulfur ( $553 \mathrm{mg}, 17.25 \mathrm{mmol}, 1.15$ equiv) was added in one portion. The reaction stirred for $40 \mathrm{~min}$ before the addition of methyl iodide $(4.26 \mathrm{~g}, 1.87 \mathrm{~mL}$, 30.0 mmol, 2.0 equiv) and was then kept in the cooling bath, but slowly warmed to room temperature overnight. Saturated aqueous $\mathrm{NH}_{4} \mathrm{Cl}$ solution ( $90 \mathrm{~mL}$ ) was added to the reaction, the mixture separated and the aqueous layer further extracted three times using $\mathrm{Et}_{2} \mathrm{O}(2 \mathrm{x} 100 \mathrm{ml}, 1 \times 50 \mathrm{ml})$. The combined organic layers were washed with water and brine, dried over sodium sulfate, and evaporated in vacuo to yield $3.31 \mathrm{~g}(13.2 \mathrm{mmol}, 88 \%)$ crude compound $\mathbf{~} \mathbf{b}$, which slowly crystallized. ${ }^{1} \mathrm{H}$ NMR ( $\left.400 \mathrm{MHz}, \mathrm{CDCl}_{3}\right): \delta=7.57$ (d, $J=8.5 \mathrm{~Hz}, 2 \mathrm{H}), 6.99(\mathrm{~d}, J=8.6 \mathrm{~Hz}, 2 \mathrm{H}), 2.45(\mathrm{~s}, 3 \mathrm{H}) \mathrm{ppm}$ (impurity signals omitted). ${ }^{13} \mathrm{C}(\mathrm{APT}) \mathrm{NMR}$ (100 $\mathrm{MHz}$, $\left.\mathrm{CDCl}_{3}\right): \delta=138.7(\mathrm{C}), 137.7(\mathrm{CH}), 128.3(\mathrm{CH}), 89.3(\mathrm{C}), 15.8$ $\left(\mathrm{CH}_{3}\right)$ ppm (impurity signals omitted).

General procedure for the synthesis of 1,4 -di(thioalkyl)benzenes $2 \mathrm{a}$-d in a microwave reactor. 1,4-Diiodobenzene (990 $\mathrm{mg}$, $3.0 \mathrm{mmol}$, 1.0 equiv), $\mathrm{CuI}(57 \mathrm{mg}, 0.3$ mmol, o.1 equiv), and $\mathrm{K}_{3} \mathrm{PO}_{4}(2.61 \mathrm{~g}, 12.3 \mathrm{mmol}$, 4.1 equiv) were weighed into a $20 \mathrm{~mL}$ reaction vial and purged with argon. The respective alkylthiol ( $6.6 \mathrm{mmol}, 2.2$ equiv) and the solvent 1,2-dimethoxyethane (DME) ( $15 \mathrm{~mL}, 0.2 \mathrm{M}$ ) were purged with argon and added to the vial, which was then sealed and heated to $180^{\circ} \mathrm{C}$ while stirring in a microwave reactor. After reaching $180^{\circ} \mathrm{C}$, which usually took about 15-20 min, this temperature was kept for $2 \mathrm{~h}$. After cooling, the reaction was then poured on $100 \mathrm{~mL}$ water and extracted three times with $\mathrm{CH}_{2} \mathrm{Cl}_{2}(2 \mathrm{x} 100 \mathrm{~mL}, 1 \times 50 \mathrm{~mL})$. The combined organic layers were dried over $\mathrm{Na}_{2} \mathrm{SO}_{4}$ and the solvent was evaporated in vacuo. The residue was purified by flash chromatography, dry loading a $40 \mathrm{~g}$ silica column (compound dissolved in $\mathrm{CH}_{2} \mathrm{Cl}_{2}, 8 \mathrm{~g}$ silica added, solvent removed in vacuo) and using petroleum ether as the eluent.

Scale-up ( $2 \mathbf{a}$ and $\mathbf{2 b}$ only): Four consecutive microwave reactions were carried out as described above, poured on 250 $\mathrm{mL}$ water together and extracted three times with $\mathrm{CH}_{2} \mathrm{Cl}_{2}$ (2X $200 \mathrm{~mL}, 1 \mathrm{x} 100 \mathrm{~mL}$ ). The combined organic layers were dried over $\mathrm{Na}_{2} \mathrm{SO}_{4}$ and the solvent was evaporated in vacuo. The residue was purified by flash chromatography, dry loading a $90 \mathrm{~g}$ silica column (compound dissolved in $\mathrm{CH}_{2} \mathrm{Cl}_{2}$, $30 \mathrm{~g}$ silica added, solvent removed in vacuo) and using petroleum ether as the eluent.

2a: Synthesis according to the general procedure using 2ethyl-1-hexanethiol (966 mg, $1.15 \mathrm{~mL}, 6.6 \mathrm{mmol}, 2.2$ equiv). Column chromatography yielded $838 \mathrm{mg}(2.29 \mathrm{mmol}, 76 \%)$ of slightly yellow liquid 2a. Scale-up: $3.96 \mathrm{~g}$ (10.8 mmol, 90\%). ${ }^{1} \mathrm{H}$ NMR (6oo MHz, $\left.\mathrm{CDCl}_{3}\right): \delta=7.23(\mathrm{~s}, 4 \mathrm{H}), 2.87(\mathrm{~d}$, $J=6.4 \mathrm{~Hz}, 4 \mathrm{H}), 1.58-1.52(\mathrm{~m}, 2 \mathrm{H}), 1.51-1.33(\mathrm{~m}, 8 \mathrm{H}), 1.32-1.22$ $(\mathrm{m}, 8 \mathrm{H})$, o.91-0.85 $(\mathrm{m}, 12 \mathrm{H})$ ppm. ${ }^{13} \mathrm{C}(\mathrm{APT}) \mathrm{NMR}(15 \mathrm{O} \mathrm{MHz}$, $\left.\mathrm{CDCl}_{3}\right): \delta=135.0(\mathrm{C}), 129.7(\mathrm{CH})$, $39.0\left(\mathrm{CH} / \mathrm{CH}_{3}\right), 38.6$ $\left(\mathrm{CH}_{2}\right), 32.4\left(\mathrm{CH}_{2}\right), 28.9\left(\mathrm{CH}_{2}\right), 25.6\left(\mathrm{CH}_{2}\right), 23.1\left(\mathrm{CH}_{2}\right), 14.2$ $\left(\mathrm{CH} / \mathrm{CH}_{3}\right), 10.9\left(\mathrm{CH} / \mathrm{CH}_{3}\right)$ ppm. HRMS (APCI/Orbitrap) $\mathrm{m} / \mathrm{z}$ : $[\mathrm{M}]^{+}$Calcd for $\mathrm{C}_{22} \mathrm{H}_{38} \mathrm{~S}_{2}$ 366.24094; Found 366.24088.

2b: Synthesis according to the general procedure using 3,7dimethyl-1-octanethiol ( $1.15 \mathrm{~g}, 6.6 \mathrm{mmol}, 2.2$ equiv). Column chromatography yielded $914 \mathrm{mg}(2.16 \mathrm{mmol}, 72 \%)$ of slightly yellow liquid $\mathbf{2 b}$. Scale-up: $4.45 \mathrm{~g}(10.5 \mathrm{mmol}, 88 \%)$. ${ }^{1} \mathrm{H}$ NMR $\left(600 \mathrm{MHz}, \mathrm{CDCl}_{3}\right): \delta=7.23(\mathrm{~s}, 4 \mathrm{H}), 2.95-2.83(\mathrm{~m}$, $\left.{ }_{4} \mathrm{H}\right), 1.67-1.42(\mathrm{~m}, 8 \mathrm{H}), 1.32-1.19(\mathrm{~m}, 6 \mathrm{H}), 1.16-1.08(\mathrm{~m}, 6 \mathrm{H})$, $0.89(\mathrm{~d}, J=6.6 \mathrm{~Hz}, 6 \mathrm{H}), 0.86(\mathrm{~d}, J=6.7 \mathrm{~Hz}, 12 \mathrm{H}) \mathrm{ppm}$. ${ }^{13} \mathrm{C}(\mathrm{APT}) \mathrm{NMR}\left(150 \mathrm{MHz}, \mathrm{CDCl}_{3}\right): \delta=134.5(\mathrm{C}), 129.7(\mathrm{CH})$, $39.3\left(\mathrm{CH}_{2}\right), 37.0\left(\mathrm{CH}_{2}\right), 36.3\left(\mathrm{CH}_{2}\right), 32.4\left(\mathrm{CH} / \mathrm{CH}_{3}\right), 31.9$ $\left(\mathrm{CH}_{2}\right), 28.1\left(\mathrm{CH} / \mathrm{CH}_{3}\right), 24.8\left(\mathrm{CH}_{2}\right), 22.8\left(\mathrm{CH} / \mathrm{CH}_{3}\right), 22.7$ $\left(\mathrm{CH} / \mathrm{CH}_{3}\right), 19.5\left(\mathrm{CH} / \mathrm{CH}_{3}\right)$ ppm. HRMS (APCI/Orbitrap) $\mathrm{m} / \mathrm{z}$ : [M] ${ }^{+}$Calcd for $\mathrm{C}_{26} \mathrm{H}_{46} \mathrm{~S}_{2}$ 422.30354; Found 422.30345 . 
2c: Synthesis according to the general procedure using 1hexanethiol (78o mg, 0.94 mL, $6.6 \mathrm{mmol}, 2.2$ equiv). Column chromatography yielded $661 \mathrm{mg}(2.13 \mathrm{mmol}, 71 \%)$ of white solid 2c. ${ }^{1} \mathrm{H}$ NMR $\left(600 \mathrm{MHz}, \mathrm{CDCl}_{3}\right): \delta=7.23(\mathrm{~s}, 4 \mathrm{H})$, $2.88(\mathrm{t}, J=7.4 \mathrm{~Hz}, 4 \mathrm{H}), 1.62$ (quint, $J=7.5 \mathrm{~Hz}, 4 \mathrm{H}$ ), 1.41 (quint, $J=7.4 \mathrm{~Hz}, 4 \mathrm{H}), 1.33-1.24(\mathrm{~m}, 8 \mathrm{H}), 0.88(\mathrm{t}, J=6.9 \mathrm{~Hz}$, $6 \mathrm{H})$ ppm. ${ }^{13} \mathrm{C}$ (APT) NMR (15o MHz, $\mathrm{CDCl}_{3}$ ): $\delta=134.5$ (C), $129.8(\mathrm{CH}), 34.1\left(\mathrm{CH}_{2}\right), 31.5\left(\mathrm{CH}_{2}\right), 29.2\left(\mathrm{CH}_{2}\right), 28.6\left(\mathrm{CH}_{2}\right)$, $22.7\left(\mathrm{CH}_{2}\right), 14.2\left(\mathrm{CH}_{3}\right) \mathrm{ppm}$. HRMS (APCI/Orbitrap) m/z: $[\mathrm{M}]^{+}$Calcd for $\mathrm{C}_{18} \mathrm{H}_{30} \mathrm{~S}_{2}$ 310.17834; Found 310.17847 .

2d: Synthesis according to the general procedure using 1dodecanethiol ( $1.34 \mathrm{~g}, 1.58 \mathrm{~mL}, 6.6 \mathrm{mmol}, 2.2$ equiv). Column chromatography yielded $1.15 \mathrm{~g}(2.37 \mathrm{mmol}, 79 \%)$ of white solid 2d. ${ }^{~} \mathrm{H}$ NMR $\left(600 \mathrm{MHz}, \mathrm{CDCl}_{3}\right): \delta=7.23(\mathrm{~s}, 4 \mathrm{H})$, $2.88(\mathrm{t}, J=7.4 \mathrm{~Hz}, 4 \mathrm{H}), 1.62$ (quint, $J=7.5 \mathrm{~Hz}, 4 \mathrm{H}), 1.4 \mathrm{O}$ (quint, $J=7.4 \mathrm{~Hz}, 4 \mathrm{H})$, 1.32-1.21 (m, $32 \mathrm{H}), 0.88(\mathrm{t}, J=7.0 \mathrm{~Hz}$, 6H) ppm. ${ }^{3} \mathrm{C}(\mathrm{APT}) \mathrm{NMR}\left(150 \mathrm{MHz}, \mathrm{CDCl}_{3}\right): \delta=134.5$ (C), 129.7 $(\mathrm{CH})$, 34.1 $\left(\mathrm{CH}_{2}\right)$, $32.1\left(\mathrm{CH}_{2}\right), 29.80\left(\mathrm{CH}_{2}\right), 29.78\left(\mathrm{CH}_{2}\right)$, $29.73\left(\mathrm{CH}_{2}\right), 29.65\left(\mathrm{CH}_{2}\right), 29.5\left(\mathrm{CH}_{2}\right), 29.31\left(\mathrm{CH}_{2}\right), 29.27$ $\left(\mathrm{CH}_{2}\right)$, 29.0 $\left(\mathrm{CH}_{2}\right), 22.8\left(\mathrm{CH}_{2}\right), 14.3\left(\mathrm{CH}_{3}\right)$ ppm. HRMS (APCI/Orbitrap) m/z: [M] ${ }^{+}$Calcd for $\mathrm{C}_{30} \mathrm{H}_{54} \mathrm{~S}_{2}$ 478.36614; Found 478.36572 .

Alternative procedure using conventional heating for the synthesis of 1,4-di(thioalkyl)benzenes 2a-d on the example of $2 \mathrm{~d}$. 1,4-Diiodobenzene (330 $\mathrm{mg}, 1.0 \mathrm{mmol}$, 1.0 equiv), $\mathrm{CuI}$ (19 mg, o.1 mmol, o.1 equiv), and $\mathrm{K}_{3} \mathrm{PO}_{4}$ (870 $\mathrm{mg}$, $4.1 \mathrm{mmol}$, 4.1 equiv) were weighed into a $5 \mathrm{~mL}$ reaction vial and purged with argon. The respective 1-dodecanethiol (445 mg, $2.2 \mathrm{mmol}, 2.2$ equiv) and the solvent 1,2-dimethoxyethane (DME) $(5 \mathrm{~mL}, 0.2 \mathrm{M})$ were purged with argon and added to the vial, which was then heated to $120^{\circ} \mathrm{C}$ by conventional heating while stirring. After 5 days, the reaction was poured into $100 \mathrm{~mL}$ water and extracted three times with $\mathrm{CH}_{2} \mathrm{Cl}_{2}$ (1x $100 \mathrm{~mL}, 2 \mathrm{x} 50 \mathrm{~mL}$ ). The combined organic layers were dried over $\mathrm{Na}_{2} \mathrm{SO}_{4}$ and the solvent was evaporated in vacuo. The residue was purified by flash chromatography, dry loading an $8 \mathrm{~g}$ silica column (compound dissolved in $\mathrm{CH}_{2} \mathrm{Cl}_{2}, 3 \mathrm{~g}$ silica added, solvent removed in vacuo) and using petroleum ether as the eluent. Evaporation of the solvent afforded $331 \mathrm{mg}$ (o.69 mmol, $69 \%)$ of white solid $\mathbf{2 d .}$

General procedure for the synthesis of 1,4 -di(thioalkyl)benzenes 2e-h. Crude 1-iodo-4-(thiomethyl)benzene lb (750 mg, $3.0 \mathrm{mmol}$, 1.o equiv), CuI ( $57 \mathrm{mg}, 0.3 \mathrm{mmol}$, o.1 equiv), and $\mathrm{K}_{3} \mathrm{PO}_{4}(2.61 \mathrm{~g}, 12.3 \mathrm{mmol}$, 4.1 equiv) were weighed into a $20 \mathrm{ml}$ reaction vial and purged with argon. The respective alkylthiol ( $3.6 \mathrm{mmol}, 1.2$ equiv) and the solvent 1,2-dimethoxyethane (DME) ( $15 \mathrm{~mL}, 0.2 \mathrm{M})$ were purged with argon and added to the vial, which was then sealed and heated to $180^{\circ} \mathrm{C}$ while stirring in a microwave reactor. After reaching $180^{\circ} \mathrm{C}$, which usually took about 15$20 \mathrm{~min}$, this temperature was kept for $2 \mathrm{~h}$. The reaction was then poured on $100 \mathrm{~mL}$ water and extracted three times with $\mathrm{CH}_{2} \mathrm{Cl}_{2}(2 \times 100 \mathrm{~mL}, 1 \times 50 \mathrm{~mL})$. The combined organic layers were dried over $\mathrm{Na}_{2} \mathrm{SO}_{4}$ and the solvent was evaporated in vacuo. The residue was purified by flash chromatography, dry loading a $40 \mathrm{~g}$ silica column (compound dissolved in $\mathrm{CH}_{2} \mathrm{Cl}_{2}, 6 \mathrm{~g}$ silica added, solvent removed in vacuo) and using petroleum ether as the eluent. 2e: Synthesis according to the general procedure using 2ethyl-1-hexanethiol ( $527 \mathrm{mg}$, o.62 $\mathrm{mL}, 3.6 \mathrm{mmol}$, 1.2 equiv). Column chromatography yielded $643 \mathrm{mg}(2.39 \mathrm{mmol}, 80 \%)$ of slightly yellow liquid 2e. ${ }^{1} \mathrm{H}$ NMR $\left(600 \mathrm{MHz}, \mathrm{CDCl}_{3}\right): \delta=$ $7.26(\mathrm{~d}, J=8.5 \mathrm{~Hz}, 2 \mathrm{H}), 7.17(\mathrm{~d}, J=8.5 \mathrm{~Hz}, 2 \mathrm{H}), 2.86(\mathrm{~d}, J=$ $6.4 \mathrm{H}, 2 \mathrm{H}), 2.47(\mathrm{~s}, 3 \mathrm{H}), 1.54$ (sept, $J=6.3 \mathrm{~Hz}, 1 \mathrm{H}$ ), 1.51-1.33 (m, $4 \mathrm{H}), 1.32-1.21(\mathrm{~m}, 4 \mathrm{H})$, 0.91-0.85 (m, 6H) ppm. ${ }^{13} \mathrm{C}(\mathrm{APT})$ NMR (150 MHz, $\left.\mathrm{CDCl}_{3}\right): \delta=135.9(\mathrm{C})$, $134.3(\mathrm{C})$, $130.0(\mathrm{CH})$, $127.5(\mathrm{CH}), 39.0\left(\mathrm{CH} / \mathrm{CH}_{3}\right), 38.8\left(\mathrm{CH}_{2}\right), 32.4\left(\mathrm{CH}_{2}\right), 28.9$ $\left(\mathrm{CH}_{2}\right), \quad 25.6\left(\mathrm{CH}_{2}\right), \quad 23.1 \quad\left(\mathrm{CH}_{2}\right), \quad 16.3\left(\mathrm{CH} / \mathrm{CH}_{3}\right), \quad 14.2$ $\left(\mathrm{CH} / \mathrm{CH}_{3}\right), 10.9\left(\mathrm{CH} / \mathrm{CH}_{3}\right)$ ppm. HRMS (APCI/Orbitrap) $\mathrm{m} / \mathrm{z}$ : [M] ${ }^{+}$Calcd for $\mathrm{C}_{15} \mathrm{H}_{24} \mathrm{~S}_{2}$ 268.13139; Found 268.13152.

2f: Synthesis according to the general procedure using 3,7dimethyl-1-octanethiol (628 mg, $3.6 \mathrm{mmol}, 1.2$ equiv). Column chromatography yielded $704 \mathrm{mg}(2.37 \mathrm{mmol}, 79 \%)$ of slightly yellow liquid 2 f. ${ }^{1} \mathrm{H}$ NMR $\left.\left(600 \mathrm{MHz}^{\mathrm{CDCl}}\right)_{3}\right): \delta=$ $7.26(\mathrm{~d}, J=8.5 \mathrm{~Hz}, 2 \mathrm{H}), 7.18(\mathrm{~d}, J=8.5 \mathrm{~Hz}, 2 \mathrm{H}), 2.95-2.82$ $(\mathrm{m}, 2 \mathrm{H}), 2.47(\mathrm{~s}, 3 \mathrm{H}), 1.66-1.4 \mathrm{O}(\mathrm{m}, 4 \mathrm{H}), 1.32-1.18(\mathrm{~m}, 3 \mathrm{H})$, 1.16-1.07 $\left(\mathrm{m},{ }_{3} \mathrm{H}\right), 0.88\left(\mathrm{~d}, J=6.6 \mathrm{~Hz},{ }_{3} \mathrm{H}\right), 0.86(\mathrm{~d}, J=6.6$ $\mathrm{Hz}, 6 \mathrm{H}) \mathrm{ppm} .{ }^{13} \mathrm{C}(\mathrm{APT}) \mathrm{NMR}\left(15 \mathrm{OHH}, \mathrm{CDCl}_{3}\right): \delta=136.2$ (C), $133.6(\mathrm{C})$, $130.1(\mathrm{CH}), 127.4(\mathrm{CH}), 39.3\left(\mathrm{CH}_{2}\right)$, 37.0 $\left(\mathrm{CH}_{2}\right)$, $36.4\left(\mathrm{CH}_{2}\right), 32.3\left(\mathrm{CH} / \mathrm{CH}_{3}\right), 32.2\left(\mathrm{CH}_{2}\right), 28.1\left(\mathrm{CH} / \mathrm{CH}_{3}\right), 24.8$ $\left(\mathrm{CH}_{2}\right), 22.8\left(\mathrm{CH} / \mathrm{CH}_{3}\right), 22.7\left(\mathrm{CH} / \mathrm{CH}_{3}\right), 19.5\left(\mathrm{CH} / \mathrm{CH}_{3}\right), 16.3$ $\left(\mathrm{CH} / \mathrm{CH}_{3}\right) \mathrm{ppm}$. HRMS (APCI/Orbitrap) m/z: [M] ${ }^{+}$Calcd for $\mathrm{C}_{17} \mathrm{H}_{28} \mathrm{~S}_{2} 296.16269$; Found 296.16250.

2g: Synthesis according to the general procedure using 1hexanethiol ( $426 \mathrm{mg}, 0.51 \mathrm{~mL}, 3.6 \mathrm{mmol}, 1.2$ equiv). Column chromatography yielded $568 \mathrm{mg}(2.36 \mathrm{mmol}, 79 \%)$ of white solid 2g. ${ }^{~} \mathrm{H}$ NMR $\left(600 \mathrm{MHz}, \mathrm{CDCl}_{3}\right): \delta=7.26(\mathrm{~d}, J=8.5 \mathrm{~Hz}$, $2 \mathrm{H}), 7.18(\mathrm{~d}, J=8.5 \mathrm{~Hz}, 2 \mathrm{H}), 2.87(\mathrm{t}, J=7.3 \mathrm{~Hz}, 2 \mathrm{H}), 2.47(\mathrm{~s}$, $3 \mathrm{H}$ ), 1.61 (quint, $J=7.5 \mathrm{~Hz}, 2 \mathrm{H}$ ), 1.40 (quint, $J=7.4 \mathrm{~Hz}, 2 \mathrm{H}$ ), 1.33-1.24 (m, $4 \mathrm{H}), 0.88(\mathrm{t}, J=7.0 \mathrm{~Hz}, 3 \mathrm{H}) \mathrm{ppm} .{ }^{13} \mathrm{C}(\mathrm{APT})$ NMR (15o MHz, $\left.\mathrm{CDCl}_{3}\right): \delta=136.2(\mathrm{C}), 133.6(\mathrm{C}), 130.2(\mathrm{CH})$, 127.4 (CH), 34.3 $\left(\mathrm{CH}_{2}\right), 31.5\left(\mathrm{CH}_{2}\right), 29.3\left(\mathrm{CH}_{2}\right), 28.6\left(\mathrm{CH}_{2}\right)$, $22.7 \quad\left(\mathrm{CH}_{2}\right), \quad 16.3 \quad\left(\mathrm{CH}_{3}\right), \quad 14.2 \quad\left(\mathrm{CH}_{3}\right) \quad$ ppm. HRMS (APCI/Orbitrap) m/z: [M] ${ }^{+}$Calcd for $\mathrm{C}_{13} \mathrm{H}_{20} \mathrm{~S}_{2}$ 240.10009; Found 240.10021.

2h: Synthesis according to the general procedure using 1dodecanethiol ( $729 \mathrm{mg}, 0.86 \mathrm{~mL}, 3.6 \mathrm{mmol}, 1.2$ equiv). Column chromatography yielded $759 \mathrm{mg}(2.34 \mathrm{mmol}, 78 \%)$ of white solid 2h. ${ }^{1} \mathrm{H}$ NMR (6oo MHz, $\left.\mathrm{CDCl}_{3}\right): \delta=7.26$ (d, $J=$ $8.5 \mathrm{~Hz}, 2 \mathrm{H}), 7.18(\mathrm{~d}, J=8.5 \mathrm{~Hz}, 2 \mathrm{H}), 2.87(\mathrm{t}, J=7.4 \mathrm{~Hz}, 2 \mathrm{H})$, $2.47(\mathrm{~s}, 3 \mathrm{H}$ ), 1.61 (quint, $J=7.5 \mathrm{~Hz}, 2 \mathrm{H}$ ), 1.39 (quint, $J=7.3$ $\mathrm{Hz}, 2 \mathrm{H}), 1.32-1.21(\mathrm{~m}, 16 \mathrm{H}), 0.88(\mathrm{t}, J=7.2 \mathrm{~Hz}, 3 \mathrm{H}) \mathrm{ppm}$. ${ }^{13} \mathrm{C}(\mathrm{APT}) \mathrm{NMR}\left(150 \mathrm{MHz}, \mathrm{CDCl}_{3}\right): \delta=136.2(\mathrm{C}), 133.6(\mathrm{C})$, $130.2(\mathrm{CH}), 127.4(\mathrm{CH}), 34.3\left(\mathrm{CH}_{2}\right), 32.1\left(\mathrm{CH}_{2}\right), 29.79\left(\mathrm{CH}_{2}\right)$, $29.78\left(\mathrm{CH}_{2}\right), 29.73\left(\mathrm{CH}_{2}\right), 29.65\left(\mathrm{CH}_{2}\right), 29.5\left(\mathrm{CH}_{2}\right), 29.31$ $\left(\mathrm{CH}_{2}\right), 29.30\left(\mathrm{CH}_{2}\right), 28.9\left(\mathrm{CH}_{2}\right), 22.8\left(\mathrm{CH}_{2}\right), 16.3\left(\mathrm{CH}_{3}\right), 14.3$ $\left(\mathrm{CH}_{3}\right) \mathrm{ppm}$. HRMS (APCI/Orbitrap) m/z: [M] ${ }^{+}$Calcd for $\mathrm{C}_{19} \mathrm{H}_{32} \mathrm{~S}_{2}$ 324.19399; Found 324.19387.

General procedure for the synthesis of Gilch monomers $3 a-c$ and $3 e-h$. A solution of the respective 1,4 -di(thioalkyl)benzene ( $2.0 \mathrm{mmol}$, 1.0 equiv) and paraformaldehyde (PFA) (240 mg, $8.0 \mathrm{mmol}$, 4.0 equiv) in formic acid (10 $\mathrm{mL})$ and $\mathrm{HBr}(2.8 \mathrm{~mL}, 30 \%$ in acetic acid) were heated to $70^{\circ} \mathrm{C}$ in a three-necked flask equipped with a thermometer and a $\mathrm{CaCl}_{2}$ protected condenser. PFA (240 $\mathrm{mg}$, 8.0 mmol, 4.0 equiv) and $\mathrm{HBr}(2.8 \mathrm{~mL}, 30 \%$ in acetic acid) were 
added again after $1 \mathrm{~h}, 2 \mathrm{~h}$, and $3 \mathrm{~h}$ reaction time. The reaction stirred overnight at $70^{\circ} \mathrm{C}$ and was then allowed to cool to room temperature to complete precipitation. The precipitate was filtered off, washed with small amounts of methanol, and dried in vacuo. The resulting solid was recrystallized from acetonitrile (continued stirring results in improved crystallization), filtered off, and washed with small amounts of acetonitrile.

Scale-up ( $3 \mathbf{a}$ and $3 \mathbf{b}$ only): The reactions were carried out following the same procedure as described above but using 10.0 mmol 1,4-di(thioalkyl)benzene as starting material and correspondingly increased amounts of reagents and solvents.

3a: Synthesis according to the general procedure using $\mathbf{2 a}$ (733 mg, 2.0 mmol, 1.o equiv) as starting material. Recrystallization yielded $780 \mathrm{mg}$ (1.41 mmol, 71\%) off-white solid 3a. Scale-up: $3.89 \mathrm{~g}$ (7.04 mmol, 70\%). ${ }^{1} \mathrm{H}$ NMR (6oo MHz, $\left.\mathrm{CDCl}_{3}\right): \delta=7.36(\mathrm{~s}, 2 \mathrm{H}), 4.64(\mathrm{~s}, 4 \mathrm{H}), 2.93(\mathrm{~d}, J=6.2 \mathrm{~Hz}$, $\left.{ }_{4} \mathrm{H}\right), 1.59$ (sept, $\left.J=6.3 \mathrm{~Hz}, 2 \mathrm{H}\right), 1.54-1.36(\mathrm{~m}, 8 \mathrm{H}), 1.34-1.24$ $(\mathrm{m}, 8 \mathrm{H})$, 0.92-0.88 (m, $12 \mathrm{H}) \mathrm{ppm} .{ }^{13 \mathrm{C}}$ (APT) NMR (150 MHz, $\left.\mathrm{CDCl}_{3}\right): \delta=138.3(\mathrm{C}), 135.7(\mathrm{C}), 131.9(\mathrm{CH}), 39.1\left(\mathrm{CH} / \mathrm{CH}_{3}\right)$, $38.9\left(\mathrm{CH}_{2}\right), 32.5\left(\mathrm{CH}_{2}\right), 31.4\left(\mathrm{CH}_{2}\right), 28.9\left(\mathrm{CH}_{2}\right), 25.8\left(\mathrm{CH}_{2}\right)$, 23.1 $\left(\mathrm{CH}_{2}\right)$, $14.3\left(\mathrm{CH} / \mathrm{CH}_{3}\right)$, $11.0\left(\mathrm{CH} / \mathrm{CH}_{3}\right)$ ppm. HRMS (APCI/Orbitrap) m/z: [M] ${ }^{+}$Calcd for $\mathrm{C}_{24} \mathrm{H}_{40} \mathrm{Br}_{2} \mathrm{~S}_{2}$ 550.09327; Found 550.09363.

3b: Synthesis according to the general procedure using $\mathbf{2 b}$ (846 mg, $2.0 \mathrm{mmol}$, 1.o equiv) as starting material. Recrystallization yielded $793 \mathrm{mg}$ (1.30 mmol, 65\%) off-white solid 3b. Scale-up: $4.75 \mathrm{~g}(7.81 \mathrm{mmol}, 78 \%)$. ${ }^{1} \mathrm{H} \mathrm{NMR}(600 \mathrm{MHz}$, $\left.\mathrm{CDCl}_{3}\right): \delta=7.36(\mathrm{~s}, 2 \mathrm{H}), 4.63(\mathrm{~s}, 4 \mathrm{H}), 3.02-2.90(\mathrm{~m}, 4 \mathrm{H}), 1.71^{-}$ $1.56(\mathrm{~m}, 4 \mathrm{H}), 1.54-1.45(\mathrm{~m}, 4 \mathrm{H}), 1.33-1.20(\mathrm{~m}, 6 \mathrm{H}), 1.18-1.09$ $(\mathrm{m}, 6 \mathrm{H}), 0.91(\mathrm{~d}, J=6.5 \mathrm{~Hz}, 6 \mathrm{H}), 0.86(\mathrm{~d}, J=6.6 \mathrm{~Hz}, 12 \mathrm{H})$ ppm. ${ }^{13} \mathrm{C}(\mathrm{APT}) \mathrm{NMR}\left(15 \mathrm{O} \mathrm{MHz}, \mathrm{CDCl}_{3}\right): \delta=138.3(\mathrm{C}), 135.2$ (C), $131.8(\mathrm{CH}), 39.3\left(\mathrm{CH}_{2}\right), 37.0\left(\mathrm{CH}_{2}\right), 36.2\left(\mathrm{CH}_{2}\right), 32.4$ $\left(\mathrm{CH} / \mathrm{CH}_{3}\right), 32.2\left(\mathrm{CH}_{2}\right), 31.3\left(\mathrm{CH}_{2}\right), 28.1\left(\mathrm{CH} / \mathrm{CH}_{3}\right), 24.8$ $\left(\mathrm{CH}_{2}\right), 22.9\left(\mathrm{CH} / \mathrm{CH}_{3}\right), 22.8\left(\mathrm{CH} / \mathrm{CH}_{3}\right), 19.5\left(\mathrm{CH} / \mathrm{CH}_{3}\right) \mathrm{ppm}$. HRMS (APCI/Orbitrap) m/z: [M]+ Calcd for $\mathrm{C}_{28} \mathrm{H}_{48} \mathrm{Br}_{2} \mathrm{~S}_{2}$ 6o6.15587; Found 6o6.15582.

3c: Synthesis according to the general procedure using $\mathbf{2 c}$ (621 mg, 2.0 mmol, 1.o equiv) as starting material. Recrystallization yielded $618 \mathrm{mg}$ (1.24 mmol, 62\%) white solid 3c. ${ }^{1} \mathrm{H}$ NMR (6oo $\mathrm{MHz}, \mathrm{CDCl}_{3}$ ): $\delta=7.35(\mathrm{~s}, 2 \mathrm{H}), 4.63(\mathrm{~s}, 4 \mathrm{H})$, $2.95(\mathrm{t}, J=7.4 \mathrm{~Hz}, 4 \mathrm{H}), 1.66$ (quint, $J=7.5 \mathrm{~Hz}, 4 \mathrm{H}$ ), 1.44 (quint, $J=7.4 \mathrm{~Hz}, 4 \mathrm{H}), 1.35-1.26(\mathrm{~m}, 8 \mathrm{H}), 0.89(\mathrm{t}, 7.0 \mathrm{~Hz}$, $6 \mathrm{H})$ ppm. ${ }^{13} \mathrm{C}(\mathrm{APT}) \mathrm{NMR}\left(150 \mathrm{MHz}, \mathrm{CDCl}_{3}\right): \delta=138.3(\mathrm{C})$, $135.2(\mathrm{C}), 131.9(\mathrm{CH}), 34.4\left(\mathrm{CH}_{2}\right), 31.5\left(\mathrm{CH}_{2}\right), 31.3\left(\mathrm{CH}_{2}\right), 29.1$ $\left(\mathrm{CH}_{2}\right), 28.7\left(\mathrm{CH}_{2}\right), 22.7\left(\mathrm{CH}_{2}\right), 14.2\left(\mathrm{CH}_{3}\right)$ ppm. HRMS (APCI/Orbitrap) m/z: $[\mathrm{M}]^{+}$Calcd for $\mathrm{C}_{20} \mathrm{H}_{32} \mathrm{Br}_{2} \mathrm{~S}_{2}$ 494.03067; Found 494.03033.

3e: Synthesis according to the general procedure using $\mathbf{2 e}$ (537 mg, 2.0 mmol, 1.o equiv) as starting material. Recrystallization yielded $498 \mathrm{mg}$ (1.10 mmol, 55\%) off-white solid 3e. ${ }^{1} \mathrm{H}$ NMR $\left(600 \mathrm{MHz} \mathrm{CDCl}_{3}\right): \delta=7.36(\mathrm{~s}, 1 \mathrm{H}), 7.27(\mathrm{~s}, 1 \mathrm{H})$, $4.66(\mathrm{~s}, 2 \mathrm{H}), 4.59(\mathrm{~s}, 2 \mathrm{H}), 2.92(\mathrm{~d}, J=6.2 \mathrm{~Hz}, 2 \mathrm{H}), 2.52(\mathrm{~s}$, $3 \mathrm{H}), 1.61-1.36\left(\mathrm{~m},{ }_{5} \mathrm{H}\right), 1.34-1.24\left(\mathrm{~m},{ }_{4} \mathrm{H}\right), 0.90(\mathrm{t}, J=7.4 \mathrm{~Hz}$, 6H) ppm. ${ }^{13} \mathrm{C}(\mathrm{APT}) \mathrm{NMR}\left(150 \mathrm{MHz} \mathrm{CDCl}_{3}\right): \delta=138.7(\mathrm{C})$, 136.75 (C), $136.66(\mathrm{C}), 135.0(\mathrm{C}), 132.1(\mathrm{CH}), 129.2(\mathrm{CH}), 39.12$ $\left(\mathrm{CH} / \mathrm{CH}_{3}\right), 39.11\left(\mathrm{CH}_{2}\right), 32.5\left(\mathrm{CH}_{2}\right), 31.5\left(\mathrm{CH}_{2}\right)$, 31.0 $\left(\mathrm{CH}_{2}\right)$,
$28.9\left(\mathrm{CH}_{2}\right), 25.7\left(\mathrm{CH}_{2}\right), 23.1\left(\mathrm{CH}_{2}\right), 16.5\left(\mathrm{CH} / \mathrm{CH}_{3}\right), 14.2$ $\left(\mathrm{CH} / \mathrm{CH}_{3}\right), 10.9\left(\mathrm{CH} / \mathrm{CH}_{3}\right)$ ppm. HRMS (APCI/Orbitrap) $\mathrm{m} / \mathrm{z}$ : $[\mathrm{M}]^{+}$Calcd for $\mathrm{C}_{17} \mathrm{H}_{26} \mathrm{Br}_{2} \mathrm{~S}_{2} 451.98372$; Found 451.98385 . 3f: Synthesis according to the general procedure using $2 f$ (593 mg, 2.0 mmol, 1.0 equiv) as starting material. Recrystallization yielded $578 \mathrm{mg}(1.20 \mathrm{mmol}, 60 \%)$ off-white solid 3f. ${ }^{1} \mathrm{H}$ NMR (6oo $\left.\mathrm{MHz}, \mathrm{CDCl}_{3}\right): \delta=7 \cdot 35(\mathrm{~s}, 1 \mathrm{H}), 7.27(\mathrm{~s}, 1 \mathrm{H})$, $4.66(\mathrm{~s}, 2 \mathrm{H}), 4.59(\mathrm{~s}, 2 \mathrm{H}), 3.01-2.89(\mathrm{~m}, 2 \mathrm{H}), 2.53(\mathrm{~s}, 3 \mathrm{H})$, 1.70-1.44 (m, $4 \mathrm{H}), 1.33-1.19\left(\mathrm{~m},{ }_{3} \mathrm{H}\right), 1.17-1.09\left(\mathrm{~m},{ }_{3} \mathrm{H}\right), 0.91(\mathrm{~d}$, $J=6.6 \mathrm{~Hz}, 3 \mathrm{H}), 0.86(\mathrm{~d}, J=6.6 \mathrm{~Hz}, 6 \mathrm{H}) \mathrm{ppm} .{ }^{13} \mathrm{C}(\mathrm{APT}) \mathrm{NMR}$ (150 $\mathrm{MHz} \mathrm{CDCl}_{3}$ ): $\delta=138.8(\mathrm{C}), 136.9(\mathrm{C}), 136.7(\mathrm{C}), 134.3$ (C), $132.1(\mathrm{CH}), 129.2(\mathrm{CH}), 39.3\left(\mathrm{CH}_{2}\right), 37.0\left(\mathrm{CH}_{2}\right), 36.2$ $\left(\mathrm{CH}_{2}\right), 32.43\left(\mathrm{CH}_{2}\right), 32.39\left(\mathrm{CH} / \mathrm{CH}_{3}\right), 31.4\left(\mathrm{CH}_{2}\right)$, 31.0 $\left(\mathrm{CH}_{2}\right)$, $28.1\left(\mathrm{CH} / \mathrm{CH}_{3}\right), 24.8\left(\mathrm{CH}_{2}\right), 22.9\left(\mathrm{CH} / \mathrm{CH}_{3}\right), 22.8\left(\mathrm{CH} / \mathrm{CH}_{3}\right)$, $19.5 \quad\left(\mathrm{CH} / \mathrm{CH}_{3}\right), \quad{ }_{16} .5 \quad\left(\mathrm{CH} / \mathrm{CH}_{3}\right) \quad$ ppm. HRMS (APCI/Orbitrap) m/z: [M] ${ }^{+}$Calcd for $\mathrm{C}_{19} \mathrm{H}_{30} \mathrm{Br}_{2} \mathrm{~S}_{2}$ 480.01502; Found 480.01503.

3g: Synthesis according to the general procedure using $\mathbf{2 g}$ (481 mg, $2.0 \mathrm{mmol}$, 1.o equiv) as starting material. Recrystallization yielded $538 \mathrm{mg}(1.26 \mathrm{mmol}, 63 \%)$ off-white solid 3g. ${ }^{1} \mathrm{H}$ NMR (6oo $\left.\mathrm{MHz}_{1} \mathrm{CDCl}_{3}\right): \delta=7 \cdot 35(\mathrm{~s}, 1 \mathrm{H}), 7.27\left(\mathrm{~s},{ }_{1} \mathrm{H}\right)$, $4.66(\mathrm{~s}, 2 \mathrm{H}), 4.59(\mathrm{~s}, 2 \mathrm{H}), 2.94(\mathrm{t}, J=7.5 \mathrm{~Hz}, 2 \mathrm{H}), 2.53(\mathrm{~s}$, $3 \mathrm{H}$ ), 1.65 (quint, $J=7.5 \mathrm{~Hz}, 2 \mathrm{H}$ ), 1.44 (quint, $J=7.4 \mathrm{~Hz}, 2 \mathrm{H}$ ), 1.34-1.26 (m, $4 \mathrm{H})$, o.89 (t, $J=7.0,3 \mathrm{H})$ ppm. ${ }^{13} \mathrm{C}($ APT) NMR (150 $\left.\mathrm{MHz} \mathrm{CDCl}_{3}\right): \delta=138.8(\mathrm{C}), 136.9(\mathrm{C}), 136.7(\mathrm{C}), 134.3$ (C), $132.2(\mathrm{CH}), 129.2(\mathrm{CH}), 34.6\left(\mathrm{CH}_{2}\right), 31.5\left(\mathrm{CH}_{2}\right), 31.4$ $\left(\mathrm{CH}_{2}\right)$, 31.0 $\left(\mathrm{CH}_{2}\right)$, $29.1\left(\mathrm{CH}_{2}\right), 28.6\left(\mathrm{CH}_{2}\right), 22.7\left(\mathrm{CH}_{2}\right), 16.5$ $\left(\mathrm{CH}_{3}\right)$, $14.2\left(\mathrm{CH}_{3}\right)$ ppm. HRMS (APCI/Orbitrap) m/z: [M]+ Calcd for $\mathrm{C}_{15} \mathrm{H}_{22} \mathrm{Br}_{2} \mathrm{~S}_{2}$ 423.95242; Found 423.95259 .

3h: Synthesis at $80^{\circ} \mathrm{C}$, but otherwise according to the general procedure using $\mathbf{2 h}$ (649 $\mathrm{mg}, \mathbf{2 . 0} \mathrm{mmol}$, 1.0 equiv) as starting material. Recrystallization yielded $721 \mathrm{mg}(1.41$ mmol, $71 \%$ ) off-white solid 3h. ' $\mathrm{H}$ NMR (6oo $\mathrm{MHz} \mathrm{CDCl}_{3}$ ): $\delta=7.35(\mathrm{~s}, 1 \mathrm{H}), 7.27(\mathrm{~s}, 1 \mathrm{H}), 4.66(\mathrm{~s}, 2 \mathrm{H}), 4.59(\mathrm{~s}, 2 \mathrm{H}), 2.94$ $(\mathrm{t}, J=7.4 \mathrm{~Hz}, 2 \mathrm{H}), 2.53(\mathrm{~s}, 3 \mathrm{H}), 1.65$ (quint, $J=7.5 \mathrm{~Hz}, 2 \mathrm{H}$ ), 1.43 (quint, $J=7.5 \mathrm{~Hz}, 2 \mathrm{H}), 1.33-1.22(\mathrm{~m}, 16 \mathrm{H}), 0.88(\mathrm{t}, J=7.0$ $\mathrm{Hz}, 3 \mathrm{H})$ ppm. ${ }^{13} \mathrm{C}(\mathrm{APT}) \mathrm{NMR}\left(150 \mathrm{MHz}, \mathrm{CDCl}_{3}\right): \delta=138.8$ (C), $136.9(\mathrm{C}), 136.7(\mathrm{C}), 134.3(\mathrm{C}), 132.2(\mathrm{CH}), 129.2(\mathrm{CH})$, $34.6\left(\mathrm{CH}_{2}\right)$, $32.1\left(\mathrm{CH}_{2}\right), 31.4\left(\mathrm{CH}_{2}\right)$, 31.0 $\left(\mathrm{CH}_{2}\right)$, 29.80 $\left(\mathrm{CH}_{2}\right)$, 29.78 $\left(\mathrm{CH}_{2}\right), 29.7\left(\mathrm{CH}_{2}\right), 29.6\left(\mathrm{CH}_{2}\right), 29.5\left(\mathrm{CH}_{2}\right), 29.3\left(\mathrm{CH}_{2}\right)$, $29.1\left(\mathrm{CH}_{2}\right)$, 29.0 $\left(\mathrm{CH}_{2}\right), 22.8\left(\mathrm{CH}_{2}\right), 16.5\left(\mathrm{CH}_{3}\right), 14.3\left(\mathrm{CH}_{3}\right)$ ppm. HRMS (APCI/Orbitrap) $\mathrm{m} / \mathrm{z}:[\mathrm{M}]^{+}$Calcd for $\mathrm{C}_{21} \mathrm{H}_{34} \mathrm{Br}_{2} \mathrm{~S}_{2}$ 508.04632; Found 508.04618.

Synthesis of Gilch monomer 3d. 1,4-Di(thioalkyl)benzene $2 \mathrm{~d}$ (1.20 g, $2.5 \mathrm{mmol}$, 1.0 equiv) and paraformaldehyde (PFA) (450 mg, $15.0 \mathrm{mmol}$, 6.o equiv) were weighed into a $20 \mathrm{ml}$ reaction vial. Trifluoroacetic acid $(2.5 \mathrm{~mL}, 0.1 \mathrm{M})$, trifluoroacetic anhydride (0.5 mL), and $1.75 \mathrm{~mL} \mathrm{HBr}$ (30\% in acetic acid) were added and the sealed, stirred vial was heated to $80^{\circ} \mathrm{C}$ for $24 \mathrm{~h}$. The reaction was then allowed to cool to room temperature; the precipitate was filtered off and washed with water and methanol. The resulting solid was purified by recrystallization from acetonitrile, yielding $838 \mathrm{mg}(1.26 \mathrm{mmol}, 50 \%)$ white solid 3d. ${ }^{1} \mathrm{H}$ NMR (6oo $\left.\mathrm{MHz}_{1} \mathrm{CDCl}_{3}\right): \delta=7.35(\mathrm{~s}, 2 \mathrm{H}), 4.63(\mathrm{~s}, 4 \mathrm{H}), 2.95(\mathrm{t}, J=7.4$ $\mathrm{Hz},{ }_{4} \mathrm{H}$ ), 1.66 (quint, $J=7.5 \mathrm{~Hz}, 4 \mathrm{H}$ ), 1.43 (quint, $J=7.3 \mathrm{~Hz}$, $\left.{ }_{4} \mathrm{H}\right), 1.33-1.22(\mathrm{~m}, 32 \mathrm{H}), 0.88(\mathrm{t}, 7.0 \mathrm{~Hz}, 6 \mathrm{H}) \mathrm{ppm} .{ }^{13} \mathrm{C}(\mathrm{APT})$ NMR (150 MHz, $\left.\mathrm{CDCl}_{3}\right): \delta=138.3(\mathrm{C}), 135.2(\mathrm{C}), 131.9(\mathrm{CH})$, 
34.4 $\left(\mathrm{CH}_{2}\right), 32.1\left(\mathrm{CH}_{2}\right), 31.3\left(\mathrm{CH}_{2}\right), 29.80\left(\mathrm{CH}_{2}\right), 29.79\left(\mathrm{CH}_{2}\right)$, $29.7\left(\mathrm{CH}_{2}\right), 29.6\left(\mathrm{CH}_{2}\right), 29.5\left(\mathrm{CH}_{2}\right), 29.3\left(\mathrm{CH}_{2}\right), 29.1\left(\mathrm{CH}_{2}\right)$, $29.0 \quad\left(\mathrm{CH}_{2}\right), \quad 22.8 \quad\left(\mathrm{CH}_{2}\right), \quad 14.3 \quad\left(\mathrm{CH}_{3}\right)$ ppm. HRMS (APCI/Orbitrap) m/z: [M] Calcd for $\mathrm{C}_{32} \mathrm{H}_{56} \mathrm{Br}_{2} \mathrm{~S}_{2}$ 662.21847; Found 662.21865.

General procedure for the preparation of S-PPVs 4a-b by Gilch polymerization at room temperature. To the respective Gilch monomer ( $0.30 \mathrm{mmol}, 1$ equiv) in an argon purged three-necked flask was added dry, degassed THF (30 $\mathrm{mL}$, 0.01 M). The solution was purged with argon for 15 min. In the meantime, $1.5 \mathrm{~mL} \mathrm{KOtBu}$ (1.0 M in THF, 1.50 mmol, 5.0 equiv) were diluted with $3 \mathrm{ml}$ dry THF (to prevent precipitation), purged with argon for $2 \mathrm{~min}$, and added to the reaction in one portion. The reaction stirred for $5 \mathrm{~h}$ at room temperature and was then slowly poured into $150 \mathrm{~mL}$ methanol for precipitation. The resulting red polymer was filtered off and dried in vacuo to determine the crude yield. For purification, the polymer was first treated with methanol $(1 \mathrm{~h})$ and then hexane $(1 \mathrm{~h})$ in a Soxhlet extractor to remove impurities. $\mathrm{CHCl}_{3}$ was finally used to extract the soluble polymer fraction. The solution was then evaporated to yield the purified red polymer.

4a: Gilch monomer za used for the polymerization. Crude yield: $71 \mathrm{mg}, 61 \%$. Purified yield: $65 \mathrm{mg}, 55 \%$. ${ }^{1} \mathrm{H}$ NMR: see preparation at $-60^{\circ} \mathrm{C}$.

4b: Gilch monomer $\mathbf{3} \mathbf{b}$ used for the polymerization. Crude yield: $70 \mathrm{mg}$, 52\%. Purified yield: $63 \mathrm{mg}, 47 \%$. ${ }^{1} \mathrm{H}$ NMR: see preparation at $-60^{\circ} \mathrm{C}$.

General procedure for the preparation of S-PPVs 4a-h by Gilch polymerization at $-60^{\circ} \mathrm{C}$. To the respective Gilch monomer (0.30 mmol, 1.o equiv) in an argon purged three-necked flask was added dry, degassed THF $(30 \mathrm{~mL}$, $0.01 \mathrm{M}$ ). The solution was purged with argon for $15 \mathrm{~min}$ and then cooled to $-60^{\circ} \mathrm{C}$ using a $\mathrm{CHCl}_{3}$-liquid $\mathrm{N}_{2}$ cooling bath. In the meantime, $1.5 \mathrm{~mL} \mathrm{KOtBu} \mathrm{(1.0} \mathrm{M} \mathrm{in} \mathrm{THF,} 1.50 \mathrm{mmol}$, 5.0 equiv) were diluted with $3 \mathrm{ml}$ dry THF (to prevent precipitation), purged with argon for $2 \mathrm{~min}$, and added to the reaction in one portion at $-60^{\circ} \mathrm{C}$ to start the polymerization. After stirring for $3 \mathrm{~h}$ at $-60^{\circ} \mathrm{C}$ to $-55^{\circ} \mathrm{C}$, the cooling bath was removed, and the reaction warmed to room temperature within about $1 \mathrm{~h}$. The reaction stirred for another hour at room temperature and was then slowly poured into 150 $\mathrm{mL}$ methanol for precipitation. The resulting red polymer was filtered off and dried in vacuo to determine the crude yield. For purification, the polymer was first treated with methanol (1 h) and then hexane ( $1 \mathrm{~h})$ in a Soxhlet extractor to remove impurities. $\mathrm{CHCl}_{3}$ was finally used to extract the soluble polymer fraction. The solution was then evaporated to yield the purified polymer.

Scale-up ( $4 \mathbf{a}$ and $\mathbf{4 b}$ only): The reactions were carried out in a $250 \mathrm{~mL}$ three-necked flask following the same procedure as described above but using $1.0 \mathrm{mmol}$ Gilch monomer as starting material and correspondingly increased amounts of $\mathrm{KO} t \mathrm{Bu}$ solution and solvents. The monomer solution was purged with argon for $30 \mathrm{~min}$, the $\mathrm{KO} t \mathrm{Bu}$ solution for $4 \mathrm{~min}$. Yields were determined for two different work-up methods, evaporation of the polymer solution obtained by Soxhlet extraction (as described above) as well as precipitation of the solution from methanol and subsequent filtration and drying of the polymer.

4a: Synthesis following the general procedures. Gilch monomer za used for the polymerization. Crude yield: $85 \mathrm{mg}$, 73\%. Purified yield: $79 \mathrm{mg}, 68 \%$. Scale-up: Crude yield: 352 mg, 90\%. Purified yield: $346 \mathrm{mg}, 89 \%$ (evaporation after Soxhlet extraction), $320 \mathrm{mg}, 82 \%$ (precipitation after Soxhlet extraction) (used for characterization and postpolymerization oxidation). ${ }^{1} \mathrm{H}$ NMR (6oo $\left.\mathrm{MHz} \mathrm{CDCl}_{3}\right): \delta=$ 7.75 (bs, $2 \mathrm{H}), 7.65$ (bs, $2 \mathrm{H}), 3.03-2.83(\mathrm{~m}, 4 \mathrm{H}), 1.69-1.36(\mathrm{~m}$, $10 \mathrm{H})$, 1.36-1.18 (m, 8H), o.96-o.8o (m, 12H) ppm. Found: $\mathrm{C}$, 73.93; H, 9.86; S, 16.11. Calc. for $\mathrm{C}_{24} \mathrm{H}_{38} \mathrm{~S}_{2}$ : C, 73.78; H, 9.8o; $\mathrm{S}, 16.41 \% . \mathrm{M}_{\mathrm{w}}=429 \mathrm{kDa}, \mathrm{M}_{\mathrm{n}}=100 \mathrm{kDa}, \mathrm{PDI}=4 \cdot 3 . \mathrm{T}_{\mathrm{d}}=$ $367^{\circ} \mathrm{C}$.

4b: Synthesis following the general procedures. Gilch monomer $\mathbf{3 b}$ used for the polymerization. Crude yield: $86 \mathrm{mg}$, 64\%. Purified yield: 75 mg, 56\%. Scale-up: Crude yield: 342 mg, 77\%. Purified yield: $299 \mathrm{mg}, 67 \%$ (evaporation after Soxhlet extraction), $130 \mathrm{mg}, 29 \%$ (precipitation after Soxhlet extraction) (used for characterization and postpolymerization oxidation). ${ }^{1} \mathrm{H}$ NMR $\left(600 \mathrm{MHz}^{\mathrm{CDCl}}\right): \delta=$ 7.73 (bs, $2 \mathrm{H}), 7.62$ (bs, $2 \mathrm{H}), 3.17-2-73(\mathrm{~m}, 4 \mathrm{H}), 1.78-1.58$ (m, $\left.{ }_{4} \mathrm{H}\right), 1.58-1.42(\mathrm{~m}, 4 \mathrm{H}), 1.34-1.18(\mathrm{~m}, 6 \mathrm{H}), 1.18-1.06(\mathrm{~m}, 6 \mathrm{H})$, $0.93(\mathrm{~d}, J=6.4 \mathrm{~Hz}, 6 \mathrm{H}), 0.84(\mathrm{~d}, J=6.5 \mathrm{~Hz}, 12 \mathrm{H}) \mathrm{ppm}$. Found: C, 74.39; $\mathrm{H}, 10.26 ; \mathrm{S}, 13.87$. Calc. for $\mathrm{C}_{28} \mathrm{H}_{46} \mathrm{~S}_{2}$ : C, 75.27 ; $10.38 ; \mathrm{S}, 14.35 \% . \mathrm{M}_{\mathrm{w}}=87 \mathrm{kDa}, \mathrm{M}_{\mathrm{n}}=31 \mathrm{kDa}, \mathrm{PDI}=$ 2.8. $\mathrm{T}_{\mathrm{d}}=378^{\circ} \mathrm{C}$.

4c: Gilch monomer $3 \mathbf{c}$ used for the polymerization. Crude yield: $62 \mathrm{mg}, 62 \%$. Purified yield: $19 \mathrm{mg}, 19 \%$.

4d: Gilch monomer 3d used for the polymerization. Crude yield: $90 \mathrm{mg}$, 6o\%. Purified yield: $25 \mathrm{mg}, 17 \%$.

4e: Gilch monomer $\mathbf{z}^{\mathbf{e}}$ used for the polymerization. Crude yield: $59 \mathrm{mg}, 67 \%$. Purified yield: $4 \mathrm{mg}, 4 \%$.

4f: Gilch monomer ze used for the polymerization. Crude yield: $47 \mathrm{mg}, 49 \%$. Purified yield: $6 \mathrm{mg}, 6 \%$.

4g: Gilch monomer ze used for the polymerization. Crude yield: $32 \mathrm{mg}$, 41\%. Purified yield: $6 \mathrm{mg}, 8 \%$.

4h: Gilch monomer ze used for the polymerization. Crude yield: $39 \mathrm{mg}, 37 \%$. Purified yield: $5 \mathrm{mg}, 5 \%$.

Synthesis of compound $3 \mathbf{a}^{\mathrm{a}} \mathrm{SO}_{2}$ by oxidation. Gilch monomer za (110 mg, $0.20 \mathrm{mmol}$, 1.0 equiv) was dissolved in $5 \mathrm{~mL} \mathrm{CH} \mathrm{Cl}_{2}$ (0.04 M). 11.7 mL DMDO (o.077 M in acetone, $0.90 \mathrm{mmol}, 4.5$ equiv) were added and the reaction stirred for $1 \mathrm{~h}$ at room temperature. The solvent and excessive DMDO were evaporated in vacuo and the crude product was purified by flash chromatography using an $8 \mathrm{~g}$ silica column and $\mathrm{CH}_{2} \mathrm{Cl}_{2}$ :petroleum ether 3:1 as the eluent. Evaporation of the combined product fractions yielded 77 mg (0.125 mmol, 63\%) white solid 3a-SO ${ }_{2} .{ }^{1} \mathrm{H}$ NMR (6oo $\mathrm{MHz}_{\mathrm{CDCl}}$ ): $\delta=8.23(\mathrm{~s}, 2 \mathrm{H}), 5.06(\mathrm{~s}, 4 \mathrm{H}), 3.34-3.26(\mathrm{~m}$, $\left.{ }_{4} \mathrm{H}\right), 2.13$ (sept, $\left.J=6.2 \mathrm{~Hz}, 2 \mathrm{H}\right), 1.59-1.51(\mathrm{~m}, 4 \mathrm{H}), 1.50-1.45$ $\left(\mathrm{m},{ }_{4} \mathrm{H}\right), 1.33-1.22(\mathrm{~m}, 8 \mathrm{H}), 0.92-0.86\left(\mathrm{~m},{ }_{12} \mathrm{H}\right)$ ppm. ${ }^{13} \mathrm{C}(\mathrm{APT}) \mathrm{NMR}\left(15 \mathrm{O} \mathrm{MHz}, \mathrm{CDCl}_{3}\right): \delta=143.3(\mathrm{C}), 138.7(\mathrm{C})$, $135.9(\mathrm{CH}), 60.2\left(\mathrm{CH}_{2}\right), 34.4\left(\mathrm{CH} / \mathrm{CH}_{3}\right), 32.5\left(\mathrm{CH}_{2}\right), 28.3$ $\left(\mathrm{CH}_{2}\right), 27.1\left(\mathrm{CH}_{2}\right), 25.8\left(\mathrm{CH}_{2}\right), 22.8\left(\mathrm{CH}_{2}\right), 14.2\left(\mathrm{CH} / \mathrm{CH}_{3}\right)$, $10.3\left(\mathrm{CH} / \mathrm{CH}_{3}\right) \mathrm{ppm}$. HRMS (ESI/Orbitrap) m/z: $[\mathrm{M}+\mathrm{Na}]^{+}$ Calcd for $\mathrm{C}_{24} \mathrm{H}_{40} \mathrm{Br}_{2} \mathrm{NaO}_{4} \mathrm{~S}_{2}$ 637.06270; Found 637.06216. 
General procedure for the preparation of $\mathrm{SO}_{2}-\mathrm{PPVs} 5 \mathrm{a}-$ b by post-polymerization oxidation. The respective $\mathrm{S}$ PPV (o.08 mmol repeating units, 1.0 equiv) was dissolved in $16 \mathrm{ml} \mathrm{CHCl}{ }_{3}(0.005 \mathrm{M})$ by stirring and heating to $150^{\circ} \mathrm{C}$ for $1 \mathrm{~h}$ in a sealed, pressure-resistant flask. The solution was cooled to r.t., $3.45 \mathrm{~mL}$ DMDO (o.094 $\mathrm{M}$ in acetone, o.32 mmol, 4.05 equiv) were added, and the reaction stirred for 10 min. Solvent and excessive DMDO were then evaporated in vacuo to yield the respective $\mathrm{SO}_{2}-\mathrm{PPV}$.

5a: Synthesis following the general procedure. S-PPV 4a $(31.3 \mathrm{mg})$ used for the reaction, which yielded $36.5 \mathrm{mg}$ $(100 \%)$ of yellow-orange polymer $\mathbf{5 a}$. Solubility in common NMR solvents too low for measurements. Found: $C, 62.11$; $\mathrm{H}, 8.07 ; \mathrm{O}, 13.58 ; \mathrm{S}, 14.49$. Calc. for $\mathrm{C}_{24} \mathrm{H}_{38} \mathrm{O}_{4} \mathrm{~S}_{2}: \mathrm{C}, 63.40 ; \mathrm{H}$, $8.42 ; \mathrm{O}, 14.07 ; \mathrm{S}, 14.10 \% . \mathrm{T}_{\mathrm{d}}=364^{\circ} \mathrm{C}$.

5b: Synthesis following the general procedure. S-PPV $\mathbf{4} \mathbf{b}$ $(35.7 \mathrm{mg})$ used for the reaction, which yielded $40.8 \mathrm{mg}$ $(100 \%)$ of yellow-orange polymer $\mathbf{5} \mathbf{b}$. Insoluble in common NMR solvents. Found: $\mathrm{C}, 64.17 ; \mathrm{H}, 8.72 ; \mathrm{O}, 12.98 ; \mathrm{S}, 12.75$. Calc. for $\mathrm{C}_{28} \mathrm{H}_{46} \mathrm{O}_{4} \mathrm{~S}_{2}$ : C, 65.84; H, 9.08; O, 12.53; S, $12.55 \%$. $\mathrm{T}_{\mathrm{d}}=372^{\circ} \mathrm{C}$.

Preparation of dimethyldioxirane (DMDO) solution in acetone. Preparation adapting a published protocol..$^{6}$ $\mathrm{NaHCO}_{3}(140 \mathrm{~g})$ was suspended in water $(250 \mathrm{~mL})$ and acetone $(200 \mathrm{~mL})$ in a $2 \mathrm{~L}$ flask. The flask was connected to a vacuum pump via two cold traps (using liquid $\mathrm{N}_{2}$-ethyl acetate for cooling). Oxone was then added in five portions (50 $\mathrm{g}$ each) and a vacuum of 400 mbar was applied after each addition until the reaction calmed down (5-10 min). The condensate in the cold traps was then collected and dried over $\mathrm{Na}_{2} \mathrm{SO}_{4}$ to yield approx. $100 \mathrm{~mL}$ DMDO solution in acetone (o.094 M). Note: Using liquid $\mathrm{N}_{2}$-acetone for cooling (instead of liquid $\mathrm{N}_{2}$-ethyl acetate) can result in clogging of the cold traps and overpressure in the flask.

The concentration of the DMDO solution was determined by dissolving a known amount of thioanisole (approx. 100 $\mathrm{mg}$ ) in $10 \mathrm{~mL} \mathrm{CH}_{2} \mathrm{Cl}_{2}$. $0.25 \mathrm{~mL}$ DMDO solution was added to $1.00 \mathrm{~mL}$ of the prepared thioanisole solution and the mixture stirred at r.t. for $5 \mathrm{~min}$. The solvent was then evaporated at $45^{\circ} \mathrm{C}$ at a pressure of 800 mbar, 600 mbar, and 400 mbar ( 5 min each). The residue was dissolved in $\mathrm{CDCl}_{3}$ and subjected to ${ }^{1} \mathrm{H}$ NMR measurements. The ratios of the integrals of the $\mathrm{CH}_{3}$ signals of unreacted thioanisole $(2.48$ $\mathrm{ppm})$ and the corresponding sulfoxide $(2.73 \mathrm{ppm})$ and sulfone $(3.06 \mathrm{ppm})$ were used to calculate the concentration (see SI for equation). Three individual measurements were carried out and averaged. Note: Removing the solvent at lower pressure results in evaporation of thioanisole and consequently in false concentrations.

\section{CONCLUSIONS AND OUTLOOK}

As our results demonstrate, Gilch polymerization is a very convenient and cheap method for the preparation of SPPVs. However, the challenges that had to be overcome to achieve an efficient monomer synthesis and a reliable polymerization give an idea of why these polymers have not been reported in the peer-reviewed literature so far.
Several conclusions can be drawn regarding the synthesis of the monomers and the preparation of the polymers: (i) 1,4-Dithioalkylbenzenes (which are required as precursors for the monomer synthesis) are best prepared by $\mathrm{Cu}$ catalyzed reactions of 1,4-diiodobenzene and alkylthiols in 1,2-dimethoxyethane (DME) in a microwave reactor, as reaction times are short, yields are high, and no ligands are needed. (ii) Formic acid (instead of acetic acid) is required as the reaction medium for the bromomethylation of $1,4^{-}$ dithioalkylbenzenes. For precursors with very long alkyl chains, a mixture of trifluoroacetic acid and trifluoroacetic anhydride is a suitable reaction medium. (iii) The polymerization must be carried out at low temperatures of $-60^{\circ} \mathrm{C}$ to obtain S-PPVs in high yields reproducibly. (iv) Two branched alkyl chains per phenylene unit are required for the polymers to be soluble. 2-Ethylhexyl groups are better suited than 3,7-dimethyloctyl groups, making S-EH-PPV the polymer of choice for future investigations. (v) Very high molecular weights can be achieved, if the S-PPVs are soluble. (vi) The developed synthetic route is also industrially relevant, as it is short, efficient, and scalable and does not require any expensive catalysts, reagents or solvents. (vii) Post-polymerization oxidation of S-PPVs to $\mathrm{SO}_{2}$-PPVs using DMDO is fast and simple but changes the material properties drastically.

It can be further concluded that the effects of replacing the alkoxy substituents of O-PPVs by thioalkyl substituents are as follows: (i) The thermal stability of S-PPVs is very high and photobleaching is weak, even dissolved in $\mathrm{CHCl}_{3}$. The stability towards photobleaching is further improved by oxidation to $\mathrm{SO}_{2}$-PPVs. (ii) The HOMO and LUMO energy levels are significantly lower than for O-PPVs. The levels are further decreased by the oxidation, which may render all-polymer solar cells using a combination of non-oxidized and oxidized polymers feasible. (iii) For S-PPVs, the photophysical measurements indicate strong interactions of the polymer backbones, most likely due to intermolecular S...S interactions.

In our opinion, S-PPVs and $\mathrm{SO}_{2}$-PPVs are likely to become the conjugated polymers of choice for studying the effects of thioalkyl and sulfone substituents; comparison to OPPVs and unsubstituted PPVs is easy, considering the large number of available studies of these polymers. Regarding applications, the excellent PLQEs of the $\mathrm{SO}_{2}-\mathrm{PPVs}$ as well as the indicated strong intermolecular interactions of $\mathrm{S}$ PPVs may be beneficial. Furthermore, S-PPVs and $\mathrm{SO}_{2}-$ PPVs are a useful pair of polymers to investigate and exploit the full potential of the post-polymerization modification using DMDO. For example, surface modification SPPV nanoparticles by DMDO could give rise to exciting properties.

\section{ASSOCIATED CONTENT}

Supporting Information. Discussion of conformational effects of PPVs and expected conformational effects of S-PPVs. ${ }^{1} \mathrm{H}$ and ${ }^{13} \mathrm{C}(\mathrm{APT}) \mathrm{NMR}$ spectra. Gel permeation chromatography (GPC). Infrared (IR) spectra. Thermogravimetric analysis (TGA) and differential scanning calorimetry (DSC). Cyclic 
voltammetry (CV). Photophysical measurements. Other syntheses: synthesis of required precursors, alternative syntheses (of $\mathbf{2 a}, \mathbf{2 e}, \mathbf{2 d}, \mathbf{3} \mathbf{a}$ and $\mathbf{3 e}$ ), synthesis of $\mathbf{3 a}$ in acetic acid (for comparison), synthesis of monomers for O-PPVs. Pictures of polymers $\mathbf{4} \mathbf{a}$ and $\mathbf{4} \mathbf{b}$. Videos of post-polymerization modifications.

This material is available free of charge via the Internet at http://pubs.acs.org.

\section{AUTHOR INFORMATION}

\section{Corresponding Author}

*E-mail: f.glocklhofer@imperial.ac.uk

\section{Author Contributions}

The manuscript was written through contributions of all authors. All authors have given approval to the final version of the manuscript.

\section{Funding Sources}

We thank TU Wien for partially funding this work.

\section{ACKNOWLEDGMENT}

We thank Andreas J. Morawietz (TU Wien) for contributing to synthetic experiments, Brigitte Holzer and Christian Hametner (TU Wien) for NMR measurements, Jieyang Huang and Michael J. Bojdys (Charles University in Prague, Institute of Organic Chemistry and Biochemistry AS CR v.v.i.) for highresolution mass spectrometry and Johannes Theiner (University of Vienna) for elemental analysis.

\section{ABBREVIATIONS}

APCI, atmospheric-pressure chemical ionization; APT, attached proton test; $\mathrm{CV}$, cyclic voltammetry; DABCO, 1,4-diazabicyclo[2.2.2] octane; DMDO, dimethyldioxirane; DME, 1,2-dimethoxyethane; DMF, dimethylformamide; DSC, differential scanning calorimetry; ESI, electrospray ionization; GPC, gel permeation chromatography; HOMO, highest occupied molecular orbital; HRMS, high resolution mass spectrometry; IR, infrared; $\mathrm{KO}$ Bu, potassium tert-butoxide; LUMO, lowest unoccupied molecular orbital; $\mathrm{M}_{\mathrm{n}}$, number average molecular weight; $\mathrm{M}_{\mathrm{w}}$, mass average molecular weight; NMR, nuclear magnetic resonance; O-PPV, dialkoxy-substituted poly(pphenylene vinylene); PDI, polydispersity index; PFA, paraformaldehyde; PL, photoluminescence; PLQE, photoluminescence quantum efficiency; PPV, poly(p-phenylene vinylene); SI, supporting information; $\mathrm{SO}_{2}-\mathrm{PPV}$, disulfone-substituted poly(p-phenylene vinylene); S-PPV, dithioalkyl-substituted poly(p-phenylene vinylene); TGA, thermogravimetric analysis; THF, tetrahydrofuran; TLC, thin-layer chromatography.

\section{REFERENCES}

1. Blayney, A. J.; Perepichka, I. F.; Wudl, F.; Perepichka, D. F., Advances and Challenges in the Synthesis of Poly(p-phenylene vinylene)-Based Polymers. Israel Journal of Chemistry 2014, 54 (56), 674-688.

2. Schönbein, A.-K.; Wagner, M.; Blom, P. W. M.; Michels, J. J., Quantifying the Kinetics of the Gilch Polymerization toward AlkoxySubstituted Poly(p-phenylene vinylene). Macromolecules 2017, 50 (13), 4952-4961.

3. Nikolić, J. D.; Wouters, S.; Romanova, J.; Shimizu, A.; Champagne, B.; Junkers, T.; Vanderzande, D.; Van Neck, D.; Waroquier, M.; Van Speybroeck, V.; Catak, S., PPV Polymerization through the Gilch Route: Diradical Character of Monomers. Chemistry - A European Journal 2015, 21 (52), 19176-19185.

4. Zaquen, N.; Lu, H.; Chang, T.; Mamdooh, R.; Lutsen, L.; Vanderzande, D.; Stenzel, M.; Junkers, T., Profluorescent PPVBased Micellar System as a Versatile Probe for Bioimaging and Drug Delivery. Biomacromolecules 2016, 17 (12), 4086-4094.

5. Peters, M.; Zaquen, N.; D'Olieslaeger, L.; Bové, H.; Vanderzande, D.; Hellings, N.; Junkers, T.; Ethirajan, A., PPVBased Conjugated Polymer Nanoparticles as a Versatile Bioimaging Probe: A Closer Look at the Inherent Optical Properties and Nanoparticle-Cell Interactions. Biomacromolecules 2016, 17 (8), 2562-2571.

6. Cui, C.; Wong, W.-Y., Effects of Alkylthio and Alkoxy Side Chains in Polymer Donor Materials for Organic Solar Cells. Macromolecular Rapid Communications 2016, 37 (4), 287-302.

7. Kong, R.; Xiao, Z.; Xie, F.; Jiang, J.; Ding, L., A D-A copolymer donor containing an alkylthio-substituted thieno[3,2-b]thiophene unit. New Journal of Chemistry 2017, 41 (8), 2895-2898.

8. Lee, D.; Hubijar, E.; Kalaw, G. J. D.; Ferraris, J. P., Enhanced and Tunable Open-Circuit Voltage using Dialkylthio Benzo[1,2-b:4,5b']dithiophene in Polymer Solar Cells. Chemistry of Materials 2012, 24 (13), 2534-2540.

9. Lee, D.; Stone, S. W.; Ferraris, J. P., A novel dialkylthio benzo[1,2-b:4,5-b[prime or minute]]dithiophene derivative for high open-circuit voltage in polymer solar cells. Chemical Communications 2011, 47 (39), 10987-10989.

10. Cheng, Y.-J.; Luo, J.; Huang, S.; Zhou, X.; Shi, Z.; Kim, T.-D.; Bale, D. H.; Takahashi, S.; Yick, A.; Polishak, B. M.; Jang, S.-H.; Dalton, L. R.; Reid, P. J.; Steier, W. H.; Jen, A. K.-Y., Donor-Acceptor Thiolated Polyenic Chromophores Exhibiting Large Optical Nonlinearity and Excellent Photostability. Chemistry of Materials 2008, 20 (15), 5047-5054.

11. Anthony, J. E.; Facchetti, A.; Heeney, M.; Marder, S. R.; Zhan, $\mathrm{X}$., n-Type Organic Semiconductors in Organic Electronics. Advanced Materials 2010, 22 (34), 3876-3892.

12. Creamer, A.; Casey, A.; Marsh, A. V.; Shahid, M.; Gao, M.; Heeney, M., Systematic Tuning of 2,1,3-Benzothiadiazole Acceptor Strength by Monofunctionalization with Alkylamine, Thioalkyl, or Alkoxy Groups in Carbazole Donor-Acceptor Polymers. Macromolecules 2017, 50 (7), 2736-2746.

13. Casey, A.; Ashraf, R. S.; Fei, Z.; Heeney, M., ThioalkylSubstituted Benzothiadiazole Acceptors: Copolymerization with Carbazole Affords Polymers with Large Stokes Shifts and High Solar Cell Voltages. Macromolecules 2014, 47 (7), 2279-2288.

14. Gong, X.; Li, G.; Feng, S.; Wu, L.; Liu, Y.; Hou, R.; Li, C.; Chen, X.; Bo, Z., Influence of polymer side chains on the photovoltaic performance of non-fullerene organic solar cells. Journal of Materials Chemistry C 2017, 5 (4), 937-942.

15. Hubijar, E.; Papadimitratos, A.; Lee, D.; Zakhidov, A.; Ferraris, J. P., Synthesis and Characterization of a Novel Symmetrical Sulfone-Substituted Polyphenylene Vinylene (SO2EH-PPV) for Applications in Light Emitting Devices. The Journal of Physical Chemistry B 2013, 117 (16), 4442-4448.

16. Gutierrez, J. J.; Luong, N.; Zapeda, D.; Ferraris, J. P., Synthesis of diblock, triblock, and star copolymers of PPV derivatives: a route to the synthesis of donor-acceptor blocks. Polymer Preprints 2004, 45 (1), 172-173.

17. Zapeda, D.; Alvarado, S. A.; Juarez, H.; Landon, P. B.; Ferraris J. P.; Gutierrez, J. J., Synthesis and Characterization of BDMOMPPV: Fully Soluble, Novel Sulfur-containing PPV. PMSE Preprints 2008, 99, 815-816.

18. Schwalm, T.; Wiesecke, J.; Immel, S.; Rehahn, M., The Gilch Synthesis of Poly(p-phenylene vinylenes): Mechanistic Knowledge in the Service of Advanced Materials. Macromolecular Rapid Communications 2009, 30 (15), 1295-1322.

19. Engman, L.; Hellberg, J. S. E., A general procedure for the synthesis of methylthio-, methylseleno- and methyltelluro-substituted aromatic compounds. Journal of Organometallic Chemistry 1985, 296 (3), 357-366.

20. Glöcklhofer, F.; Lumpi, D.; Stöger, B.; Fröhlich, J., Multigram synthesis of bis[(trimethylsilyl)ethynyl]benzenes suitable for postpolymerization modification. New Journal of Chemistry 2014, 38 (6), 2229-2232.

21. Thomas, A. M.; Asha, S.; Sindhu, K. S.; Anilkumar, G., A general and inexpensive protocol for the Cu-catalyzed $\mathrm{C}-\mathrm{S}$ cross-coupling 
reaction between aryl halides and thiols. Tetrahedron Letters 2015, 56 (47), 6560-6564.

22. Sevez, G.; Pozzo, J.-L., Toward multi-addressable molecular systems: Efficient synthesis and photochromic performance of unsymmetrical bisthienylethenes. Dyes and Pigments 2011, 89 (3), 246-253.

23. Schwalm, T.; Rehahn, M., Toward Controlled Gilch Synthesis of Poly(p-phenylenevinylenes): Synthesis and Thermally Induced Polymerization of $\alpha$-Bromo-p-quinodimethanes. Macromolecules 2007, 40 (11), 3921-3928.

24. Chang, C.-P.; Wang, C.-C.; Chao, C.-Y.; Lin, M.-S., Comparisons of Optical Properties on Meta- and Para-Linkages of Copolymers for Poly(phenylene vinylene) and Poly(phenylene azomethine) with Alkylthio Group at the Side Chain. Journal of Polymer Research 2005, 12 (1), 1-7.

25. Zhang, C.; Choi, S.; Haliburton, J.; Cleveland, T.; Li, R.; Sun, S.-S.; Ledbetter, A.; Bonner, C. E., Design, Synthesis, and Characterization of a-Donor-Bridge-Acceptor-Bridge- Type Block Copolymer via Alkoxy- and Sulfone- Derivatized Poly(phenylenevinylenes). Macromolecules 2006, 39 (13), 43174326.

26. Mitchell, R. H.; lyer, V. S., An Improved Procedure for Bromomethylation of Aromatics Using Phase-Transfer Catalysis. Rapid Bis-haloalkylation. Synlett 1989, 1989 (01), 55-57.

27. Zhang, C.; Sun, J.; Li, R.; Black, S.; Sun, S.-S., Synthesis and energy gap studies of a series of sulfone-substituted polyphenylenevinylenes (SF-PPVs). Synthetic Metals 2010, 160 (1), 16-21.

28. Johansson, D. M.; Theander, M.; Srdanov, G.; Yu, G.; Inganäs, O.; Andersson, M. R., Influence of Polymerization Temperature on Molecular Weight, Photoluminescence, and Electroluminescence for a Phenyl-Substituted Poly(p-phenylenevinylene). Macromolecules 2001, 34 (11), 3716-3719.

29. Spiliopoulos, I. K.; Mikroyannidis, J. A., Synthesis of poly (pphenylene vinylene)- and poly(phenylene ethynylene)-based polymers containing p-terphenyl in the main chain with alkoxyphenyl side groups. Journal of Polymer Science Part A: Polymer Chemistry 2002, 40 (15), 2591-2600.

30. Glöcklhofer, F.; Lumpi, D.; Kohlstädt, M.; Yurchenko, O.; Würfel, U.; Fröhlich, J., Towards continuous junction (CJ) organic electronic devices: Fast and clean post-polymerization modification by oxidation using dimethyldioxirane (DMDO). Reactive and Functional Polymers 2015, 86, 16-26.

31. Schult, K. A.; Paul, D. R., Water sorption and transport in a series of polysulfones. Journal of Polymer Science Part B: Polymer Physics 1996, 34 (16), 2805-2817.

32. Su, W.-F.; Yeh, K.-M.; Chen, Y., Synthesis and optoelectronic properties of luminescent poly(p-phenylenevinylene) derivatives containing electron-transporting 1,3,4-oxadiazole groups. Journal of Polymer Science Part A: Polymer Chemistry 2007, 45 (18), 43774388.

33. Greenham, N. C.; Samuel, I. D. W.; Hayes, G. R.; Phillips, R. T.; Kessener, Y. A. R. R.; Moratti, S. C.; Holmes, A. B.; Friend, R. $\mathrm{H}$., Measurement of absolute photoluminescence quantum efficiencies in conjugated polymers. Chemical Physics Letters 1995, 241 (1), 89-96.

34. Roche, C.; Sun, H.-J.; Leowanawat, P.; Araoka, F.; Partridge, B. E.; Peterca, M.; Wilson, D. A.; Prendergast, M. E.; Heiney, P. A.; Graf, R.; Spiess, H. W.; Zeng, X.; Ungar, G.; Percec, V., A supramolecular helix that disregards chirality. Nature Chemistry 2015, 8, 80.

35. Vandeleene, S.; Van den Bergh, K.; Verbiest, T.; Koeckelberghs, G., Influence of the Polymerization Methodology on the Regioregularity and Chiroptical Properties of Poly(alkylthiothiophene)s. Macromolecules 2008, 41 (14), 51235131.

36. Mikula, H.; Svatunek, D.; Lumpi, D.; Glöcklhofer, F.; Hametner C.; Fröhlich, J., Practical and Efficient Large-Scale Preparation of Dimethyldioxirane. Organic Process Research \& Development 2013, $17(2), 313-316$ 